УДК 553.434:550.42

\title{
УСЛОВИЯ ОБРАЗОВАНИЯ И ИСТОЧНИКИ ФЛЮИДА ЮБИЛЕЙНОГО МЕДНОКОЛЧЕДАННОГО МЕСТОРОЖДЕНИЯ (ЮЖНЫЙ УРАЛ) ПО ДАННЫМ ТЕРМОБАРОГЕОХИМИИ И ИЗОТОПНО-ГЕОХИМИЧЕСКИХ ИССЛЕДОВАНИЙ
}

\author{
Целуйко Александр Сергеевич1, \\ celyukoa@rambler.ru
}

\author{
Анкушева Наталья Николаевна ${ }^{1,2}$, \\ ankusheva@mail.ru
}

\section{Садыков Сергей Ахматович1, sergei_sadykov@mail.ru}
1 Институт минералогии Южно-Уральского федерального научного центра минералогии и геоэкологии УрО РАН, Россия, 456317, г. Миасс, тер. Ильменский заповедник.
2 Южно-Уральский государственный университет, филиал в г. Миассе, Россия, 456304, г. Миасс, ул. 8 июля, 10.

\begin{abstract}
Актуальность работы связана с проблемой определения $P T$ ( $P$ - давление, $T$ - температура) и изотопно-геохимических параметров образования руд и донных сульфидных построек Юбилейного медноколчеданного месторождения, включающих палеогидротермальные трубы, сульфидные дифффузеры и биолититы, в сравнении с другими колчеданными месторождениями Южного Урала и современными сульфидными холмами.

Цель: определение условий формирования и изотопно-геохимического состава рудоносных фрлюидов, сфрормировавших донные сульфидные постройки Юбилейного месторождения.

Объектом исследования является Юбилейное медноколчеданное месторождение, расположенное в Республике Башкортостан на Южном Урале.

Методы. Содержания примесных компонентов в кальците определены на электронном микроскоne Tescan Vega 3 sbu (Институт минералогии ЮУ ФНЦ МиГ УрО РАН). Флюидные включения проанализированы в термокамере TMS-600 (Linkam) с микроскопом Olympus BX-51 (ЮУрГУ, фрилиал в г. Миассе). Газовые фразы флюидных включений в кварие определены методом рамановской

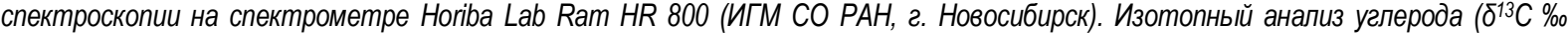
VPDB) и кислорода ( $\delta^{18} \mathrm{O} \%$ VSMOW) измерен на масс-спектрометре Delta Plus Advantage (Thermo Finnigan), сопряженном с элементным анализатором EA Flash 1112 с интерсрейсом ConFlo III (Институт минералогии ЮУ ФНЦ МиГ УрО РАН).

Результаты. Гомогенизация фрлюидных включений в кальците и кварие рудных жил Юбилейного месторождения происходила в интервале $120-225^{\circ} \mathrm{C}$, соленость захваченного фрлюида составила 3,3...10,2 мас. \% NaCl-экв. Отложение прозрачных минералов $\left(T_{\text {гом }}<200{ }^{\circ} \mathrm{C}\right)$ реликтов палеогидротермальных труб, сульфридных дифффузеров и кальцитовых прожилков в колломорфных рудах, вероятно, связано с эпигенетическими процессами преобразования колчеданных руд. Флюидные включения 8 кварие и кальците $c T_{\text {гом }}>200{ }^{\circ} \mathrm{C}$ могли образоваться во время низкотемпературных стадий первичного колчеданообразования. Изотопный состав $\delta^{13} \mathrm{C}$ и $\delta^{18} \mathrm{O}$ кальцита, а также расчетные величины $\delta^{18} \mathrm{O}_{22} \mathrm{u}$ и $\delta^{13} \mathrm{C}$ со2 фрлюида предполагают смешение морской воды и магматического фрлюида.
\end{abstract}

\section{Ключевые слова:}

Сульфидные палеогидротермальные трубы, фрлюидные включения, изотопы С и О, колчеданные месторождения, Южный Урал.

\section{Введение}

На колчеданных месторождениях в сульфидных рудах и вмещающих породах распространены прожилки и гнезда разнообразных по составу карбонатов (кальцита, арагонита, доломита, магнезита, сидерита) и кварца [1-5 и др.]. Формирование прожилков карбонатов, кварца и барита сопровождало процессы гидротермального рудообразования, диагенетического и эпигенетического преобразования колчеданных руд. Анализ флюидных включений в прозрачных минералах сульфидных руд и околорудном пространстве позволяет, например, локализовать зоны повышенных температур в колчеданных залежах, выявить роль магматического флюида и установить взаимосвязь температур кристаллизации с текстурноструктурными особенностями руд $[1,4,6]$.

Объектами исследования условий рудообразования на медноколчеданном месторождении Юбилей- ное стали реликты палеогидротермальных труб, сульфидных диффузеров и корок, запечатанные кальцитом, кварцем, баритом или сфалеритом, обнаруженные на месторождении и многих других залежах Урала [7-10]. Интервал температур гомогенизации флюидных включений в прозрачных минералах в целом ниже, чем замеренные температуры флюида на современных сульфидных гидротермальных постройках $[8,11-16]$. Однако современные сульфидные трубы, принадлежащие одной гидротермальной системе, могут значительно различаться по температурам минералообразования и солености [7]. Наличие в рудах слабометаморфизованного месторождения Юбилейное запечатанных кальцитом и кварцем сульфидных труб различного минерального состава, а также карбонатсодержащих сульфидных диффузеров и биолититов позволил оценить РТ параметры гидротермальных процессов в различных типах донных построек. 
По результатам изотопно-геохимических исследований карбонатов были оценены возможные источники воды колчеданообразующего флюида.

Приведенные данные по гомогенизации флюидных включений и изотопному составу углерода и кислорода продолжают серию работ по оценке условий формирования, газового и изотопного состава рудоносных флюидов, сформировавших донные сульфидные постройки Юбилейного месторождения [17-19].

\section{Краткая геологическая характеристика месторождения}

Юбилейное медноколчеданное месторождение находится в юго-восточной части республики Башкортостан и приурочено к Западно-Магнитогорской палеовулканической зоне, колчеданоносные комплексы которой принадлежат фронтальной части энсиматической островодужной системы [20]. Рудные залежи месторождения находятся в породах баймакбурибайской свиты $\left(\mathrm{D}_{1} e_{2} \mathrm{~b}-\mathrm{br}\right)$, представленной базальтами, бонинитами, андезибонинитами, андезитами и андезидацитами, и перекрыты породами верхнетаналыкского комплекса ( $\left.\mathrm{D}_{2} \mathrm{e}_{2} \mathrm{vtn}\right)$ : базальтами, андезибазальтами, андезитами, дацитами и риолитами (рис. 1) [21].

На месторождении установлено шесть рудных залежей, в статье рассмотрены руды Второй залежи, в которых обнаружены сульфидные палеогидротермальные трубы, биоморфные руды (биолититы), сульфидные диффузоры, корки и плиты [8-10].

Согласно фондовым материалам, кальцит на месторождении тяготеет к медно-цинковым рудам, где образует гнезда, пятнообразные выделения и прожилки в ассоциации с сульфидами, кварцем и хлоритом [22]. Карбонаты также входят в состав сплошных медно-цинково-колчеданных и медноколчеданных руд. Кальцит в ассоциации с тальком, кварцем, сфалеритом и другими сульфидами заполняет осевые каналы палеогидротермальных сульфидных труб [9]. Кальцит входит в состав ажурных карбонатнопиритовых руд, содержащих оруденелые реликты фауны и часто выполняет полости сульфидизированных биоморфоз [23].

\section{Методы исследования}

Оптические исследования кальцита и ассоциирующих сульфидных минералов проведены на микроскопе для отраженного и проходящего света Olympus BX51 с использованием цифровой камеры DP12 для фотографирования.

Содержания примесных компонентов в кальците определены с помощью сканирующего электронного микроскопа Tescan Vega 3 sbu с энергодисперсионным анализатором Oxford Instruments X-act (Институт минералогии ЮУ ФНЦ МиГ УрО РАН, аналитик И.А. Блинов).

Двухфазные флюидные включения в кварце и кальците проанализированы в термокамере TMS-600 c рабочей температурной областью от -196 до +600 ${ }^{\circ} \mathrm{C}$ на микроскопе Olympus BX-51 (ЮжноУральский государственный университет, г. Миасс, аналитик Н.Н. Анкушева) с программным пакетом
LinkSystem V-2.39. Погрешность составляет $\pm 0,1{ }^{\circ} \mathrm{C}$ при $-20 \ldots+80{ }^{\circ} \mathrm{C}$ и $\pm 1^{\circ} \mathrm{C}-$ за пределами этого интервала. Солевой состав флюида оценен по температурам эвтектик растворов включений [24-26]. Концентрации солей рассчитаны по температурам плавления последних кристаллических фаз во включениях [27]. Исследовано 126 включений в кальците.

Методом рамановской спектроскопии определены газовые фазы во включениях в кварце кварц-пиритхалькопиритовой палеогидротермальной трубы (обр. юб-12-21) (ИГМ СО РАН, г. Новосибирск, аналитик H.H. Анкушева) на спектрометре Horiba Lab Ram HR 800 с полупроводниковым детектором. Возбуждение производилось твердотельным лазером (532 нм) мощностью 50 мВт, для получения удовлетворительного соотношения сигнал/шум производилось 10 накоплений по 10 секунд. Оценка молекулярных соотношений газов без учета паров воды проведена согласно [28]. Исследовано 12 флюидных включений и снято 53 спектра. Процедуры вычитания фона и сглаживания проведены в программе Origin 8.0.

Для изотопных исследований отобраны монофракции кальцита из осевых каналов реликтов палеогидротермальных сульфидных труб, ажурных серноколчеданных руд и кальцитовых прожилков в обломочных медно-цинково-колчеданных рудах. Материал для анализа высверливался алмазным сверлом.

Изотопный анализ углерода $\left(\delta^{13} \mathrm{C} \%\right.$ VPDB) проводился на масс-спектрометре Delta Plus Advantage (Thermo Finnigan), сопряженном с элементным анализатором EA Flash 1112 с интерфейсом ConFlo III (Институт минералогии ЮУ ФНЦ МиГ УрО РАН, аналитик С.А. Садыков). В работе использовались международные стандарты NBS-19 и NBS-123. Воспроизводимость измерений $\delta^{13} \mathrm{C}$ составляет $\pm 0,06 \%$.

Определение изотопного состава кислорода $\left(\delta^{18} \mathrm{O} \%\right.$ VSMOW) сделано на масс-спектрометре Delta Plus Advantage (Thermo Finnigan), сопряженном с высокотемпературным конвектором ЕА/ТC с интерфейсом ConFlo III (Институт минералогии ЮУ ФНЦ МиГ УрО РАН, аналитик С.А. Садыков). Использовались стандарты NBS-18 и NBS-19. Воспроизводимость измерений $\delta^{18} \mathrm{O}$ составляет $\pm 0,2 \%$. Всего выполнено по 24 анализа $\delta^{13} \mathrm{C}$ и $\delta^{18} \mathrm{O}$, соответственно.

Значения $\delta^{18} \mathrm{O}_{\mathrm{H} 2 \mathrm{O}}$ и $\delta^{13} \mathrm{C}_{\mathrm{CO} 2}$ минералообразующего флюида при заданных температурах рассчитаны по формулам $\Delta=\delta^{18} \mathrm{O}-1000 \ln \alpha \mathrm{O}^{18}$ и $\Delta=\delta^{13} \mathrm{C}-1000 \ln \alpha \mathrm{C}^{13}$, соответственно [29, 30].

\section{Результаты исследования}

Колчеданные руды Юбилейного месторождения, среди которых диагностированы реликты донных сульфидных построек (палеогидротермальных труб и диффузеров), содержат многочисленные прожилки и гнезда кальцита молочно-белого, светло-серого и темно-серого цветов. В ходе работы акцент был сделан на изучение карбонатного вещества, связанного с сульфидными палеогидротермальными трубами, маркирующими выходы высокотемпературного (до 350-400 들 высокоминерализованного флюида на поверхность древнего морского дна. Реликты палеогидротермаль- 
ных труб, как и их современные аналоги, характеризуются концентрически-зональным строением, округлой или овальной формой в поперечном сечении и небольшим диаметром (до 3-4 см) одиночных трубок (рис. $1, a)$. Кальцит сосредоточен в центральном осевом канале, окруженном крустификационными, почковидными и дендритовидными агрегатами халькопирита, сфалерита и пирита.

Гнезда и мелкие прожилки кальцита зафиксированы в ажурных пиритовых агрегатах, вероятно, представляющих собой реликты сульфидных диффузоров, палеогидротермальных плит и корок (рис. 1, б). Струйное или диффузное поступление восстановленных гидротермальных флюидов и их смешение с кислородсодержащей морской водой формирует благо- приятную среду для развития пригидротермальной фауны, которая часто фиксируется в виде трубчатых оруденелых биоморфоз в колломорфных пиритовых рудах [23]. Кальцит в ассоциации с халькопиритом, сфалеритом, зернистым и фрамбоидальным пиритом заполняет внутренние пространства сульфидизированной фауны и часто обнаруживается в сосуществующих серноколчеданных рудах.

В серно-, медно- медно-цинково-колчеданных рудах распространены кальцитовые, тальк-кальцитовые и кварц-кальцитовые прожилки и гнезда (рис. 1, a). В химическом составе кальцита реликтов сульфидных построек и прожилков отмечаются примеси $\mathrm{Mn}$ (до 1,12 мас. \%) и $\mathrm{Fe}$ (до 0,22 мас. \%).
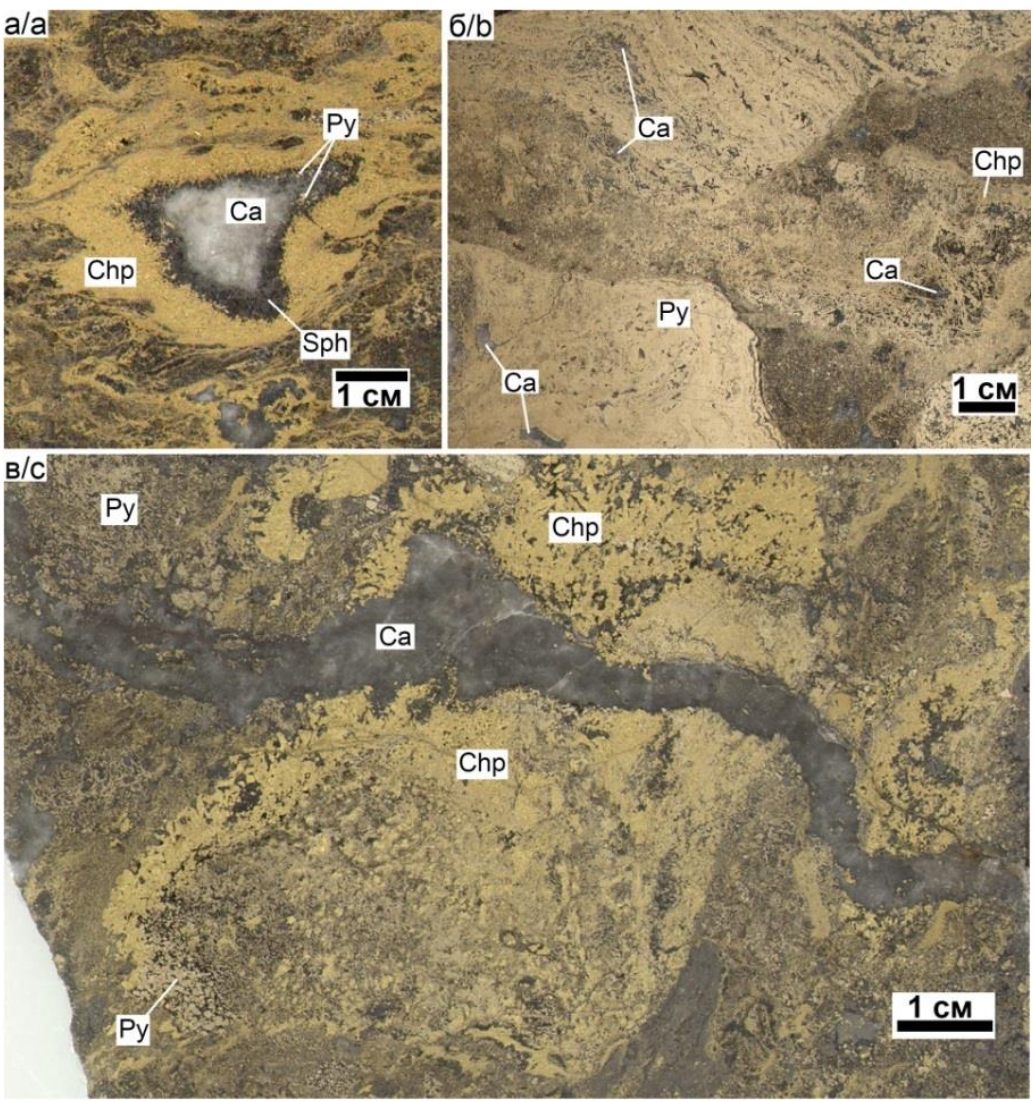

Рис. 1. Реликты сульфидных палеогидротермальных построек с кальцитовой минерализацией: а) кальиитовое заполнение осевого канала в сфалерит-пирит-халькопиритовой палеогидротермальной трубе; б) гнезда кальцита в колломорфных и тонкозернистых пиритовых агрегатах фрагментов сульфидных диффузеров; в) прожилок кальцита, секущий обломочную сульфидную руду. Ca - кальциит, Chp - халькопирит, Py - пирит, Sph-cфалерит. Полированные образиы

Fig. 1. Relics of sulfide paleohydrothermal edifices with calcite mineralization: a) calcite filling of the axial tube in the sphalerite-pyrite-chalcopyrite paleohydrothermal chimneys; b) calcite nests in collomorphic and fine-grained pyrite aggregates fragments of sulfide diffusers; c) calcite veins in clastic sulfide ore. Ca-calcite, Chp-chalcopyrite, Pypyrite, Sph-sphalerite. Polished samples

Рассматриваемый в статье кальцит был разделен на две генерации: кальцитовые прожилки, гнезда и скопления, запечатывающие каналы и полости в сульфидных постройках (рис. 2, $a-2)$, и прожилки, секущие тонкозернистые и колломорфные сульфидные руды (рис. 2, $\partial, e$ ). К первой генерации отнесен кальцит, цементирующий ажурные, почковидные и дендритовидные агрегаты пирита и халькопирита сульфидных диффузеров, запол- няющий осевые каналы палеогидротермальных труб и выполняющий сульфидизированные биоморфозы. Кальцитовые агрегаты содержат гнезда талька, мелкие включения сульфидных минералов (рис. 2, а, б) или сульфидные агрегаты, характеризующиеся закономерно ориентированным ростом (дендриты, почки, крустификации). Гнезда и прожилки кальцита в сульфидных диффузорах, палеогидротермальных плитах и корках 
заполняют полости между почковидными и зернистыми агрегатами пирита и сфалерита и при этом практически не содержат включений рудных минералов (рис. 2, 6, г).

Прожилки кальцита второй генерации мощностью до 1,0-1,5 см рассекают сплошные массивные и об- ломочные тонкозернистые и колломорфные руды различного состава. Характерной особенностью поздних кальцитовых прожилков является присутствие обломков сульфидных руд различной формы, размера, минерального состава и ориентировки.
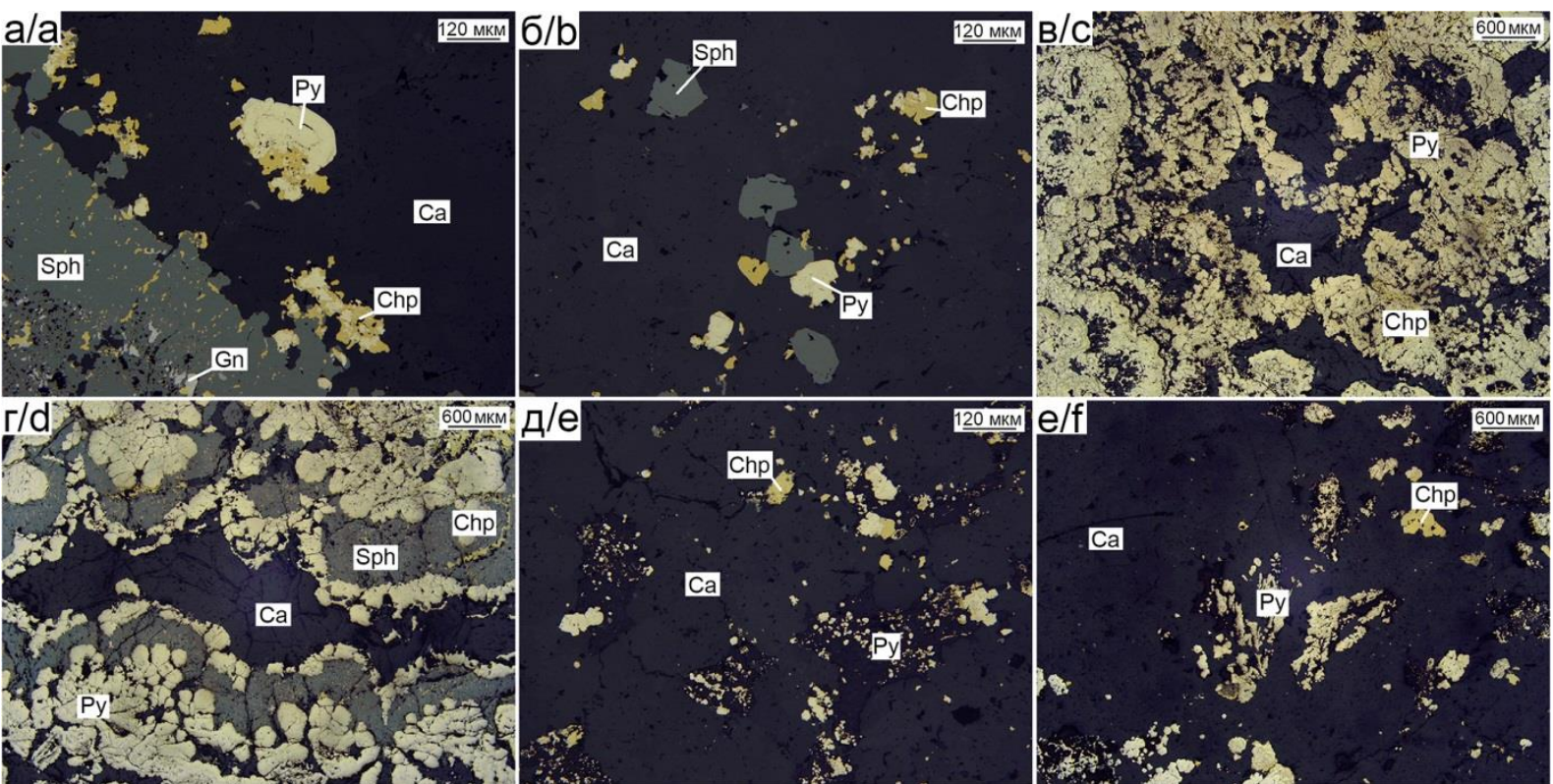

Рис. 2. Минералогические особенности кальцитового заполнения каналов палеогидротермальных труб, гнезд и прожилков в сульфидных рудах: а) агрегаты пирита (Ру) и халькопирита (Chр) в кальиите (Са) осевого канала на границе со сфалеритовой (Sph) стенкой канала с мелкими включениями галенита (Gn); б) включения халькопирита (Chp), пирита (Ру) и кристаллы сфалерита (Sph) в кальците (Са) палеогидротермальной трубы; в) гнезда кальиита (Са) в пирит-халькопиритовом агрегате (Py, Сhр) сульфидного диффузера; г) халькопирит-сфалерит-пиритовый почковидный агрегат (Sph, Chp, Py), окаймляющий прожилок кальцита (Ca) в колломорфной руде; д, е) обломки агрегатов пирита (Ру) и халькопирита (Сhр) в кальцитовом прожилке (Са). Отраженный свет

Fig. 2. Mineralogical peculiarities of calcite filling of the tubes of paleohydrothermal chimneys and veins in sulfide ores: a) aggregates of pyrite ( $\mathrm{Py})$ and chalcopyrite $(\mathrm{Chp})$ in calcite $(\mathrm{Ca})$ of the axial tube near sphalerite crustifications $(\mathrm{Sph})$ with inclusions of galena $(\mathrm{Gn}) ; \mathrm{b})$ inclusions of chalcopyrite (Chp), pyrite (Py) and crystals of sphalerite (Sph) in calcite $(\mathrm{Ca})$ of the paleohydrothermal chimneys; $\mathrm{c}$ ) calcite $(\mathrm{Ca})$ in the pyrite-chalcopyrite aggregate $(P y, C h p)$ of sulfide diffuser; $d$ ) calcite $(C a)$ veins with chalcopyrite-sphalerite-pyrite reniform aggregate (Sph, Chp, Py) in a collomorphic sulfide ore; $e, f)$ fragments of pyrite (Py) and chalcopyrite (Chp) aggregates in calcite vein (Ca). Reflected light

Для определения РТ параметров образования руд были проведены термобарогеохимические исследования синхронного с сульфидами кальцита сульфидных труб и диффузеров, а также поздних карбонатных прожилков в колчеданных рудах (рис. 3, 4). Ранее по результатам изучения флюидных включений в кварце (обр. юб-12-20-1; юб-12-21; юб-12-3) и кальците (обр. юб-11-12) палеогидротермальных труб установлены температуры $\left(\mathrm{T}_{\text {гом }}\right) \quad 100-230{ }^{\circ} \mathrm{C}$ [19]. Концентрация солей в водных растворах включений в кварце и кальците изменяется от 1 до 6,4 мас. \%

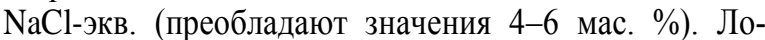
кальные изменения $\mathrm{T}_{\text {гом }}$ флюидных включений в кварце могут быть связаны с особенностями зональности сульфидной трубы: на контакте с сульфидными агрегатами кварц-1 является более высокотемпературным $\left(\mathrm{T}_{\text {гом }}=200-230^{\circ} \mathrm{C}\right)$ по сравнению с кварцем-2 $\left(\mathrm{T}_{\text {гом }}=120-140{ }^{\circ} \mathrm{C}\right)$, заполняющим центральную часть осевого канала и не содержащим включения сульфидов [19].
Флюидные включения в кальците осевых каналов двух кальцит-сфалерит-пирит-халькопиритовых палеогидротермальных труб (обр. юб-12-115 и юб-12-99-4) размером 10-15 мкм имеют остроугольную изометричную форму, расположены обособленно или малочисленными группами по 2-3 включения (рис. 3). По фазовому составу включения двухфазные (VL) объем газовой вакуоли составляет 15 \% их объема. Температуры эвтектики $\left(\mathrm{T}_{\text {эвт }}\right)$ включений в кальците труб отвечают солевым системам $\mathrm{NaCl}-\mathrm{H}_{2} \mathrm{O}$ и $\mathrm{NaCl}-\mathrm{KCl}-\mathrm{H}_{2} \mathrm{O}$ (табл. 1). Температуры гомогенизации кальцита первой из исследованных сульфидных труб (обр. юб-12-115) составляют $139-180{ }^{\circ} \mathrm{C}$ (мода $160-180{ }^{\circ} \mathrm{C}$ ). Температуры плавления последнего кристалла льда $\left(\mathrm{T}_{\text {ппк }}\right)$ $\left(-2,4 \ldots-5,2{ }^{\circ} \mathrm{C}\right)$ указывают на соленость $4-8,1$ мас. \% $\mathrm{NaCl}$-экв. Кальцитовые агрегаты второй палеогидротермальной трубы (обр. юб-12-99-4) характеризуются $\mathrm{T}_{\text {гом }}$ от 120 до $148{ }^{\circ} \mathrm{C}$ (мода $135-140{ }^{\circ} \mathrm{C}$ ). Концентрация солей составляет 3,3-6,3 мас. \% NaCl-экв. $\left(\mathrm{T}_{\text {ппк. }}-\right.$ $\left.2 . .-3,9^{\circ} \mathrm{C}\right)$. 

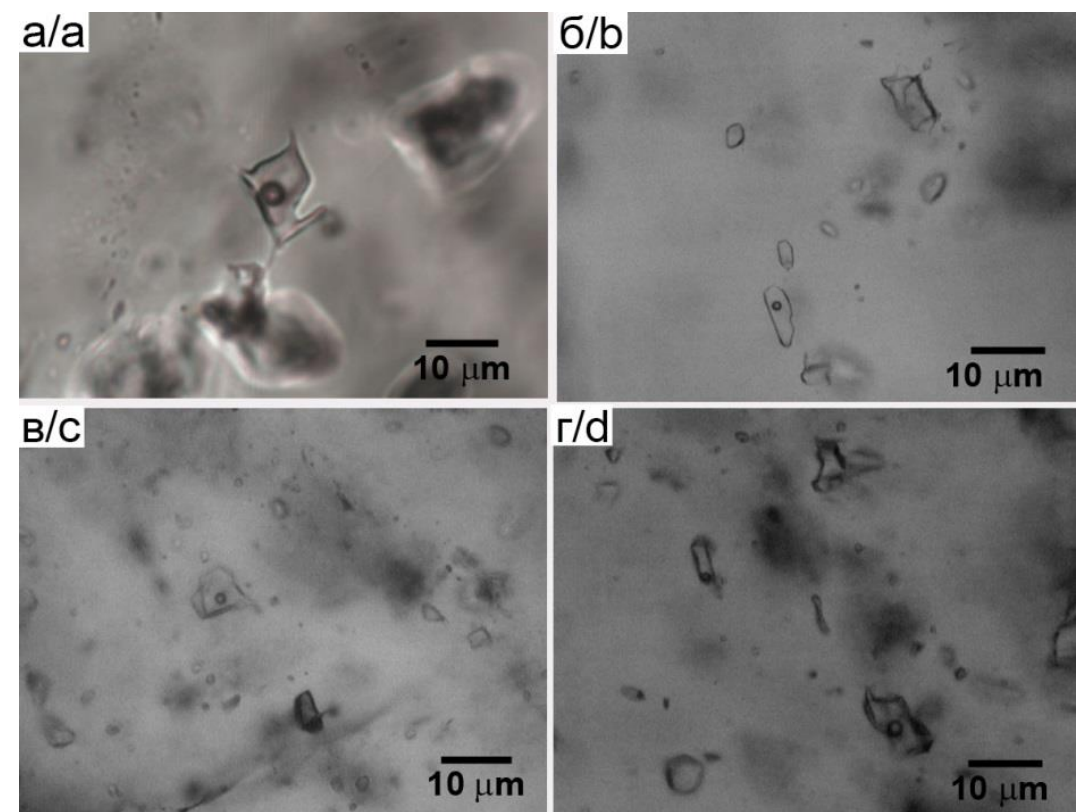

Pис. 3. Флюидные включения в кварие (а) и кальците (б-г) сульфидных руд Юбилейного месторождения

Fig. 3. Fluid inclusions in quartz (a) and calcite $(b-d)$ of sulfide ores from Yubileynoe VMS deposit

Таблица 1. Результаты термобарогеохимических исследований кальцита и квариа сульфидных руд Юбилейного месторождения

Table 1. Fluid inclusion data of calcite and quartz from sulfide ores of Yubileynoe VMS deposit

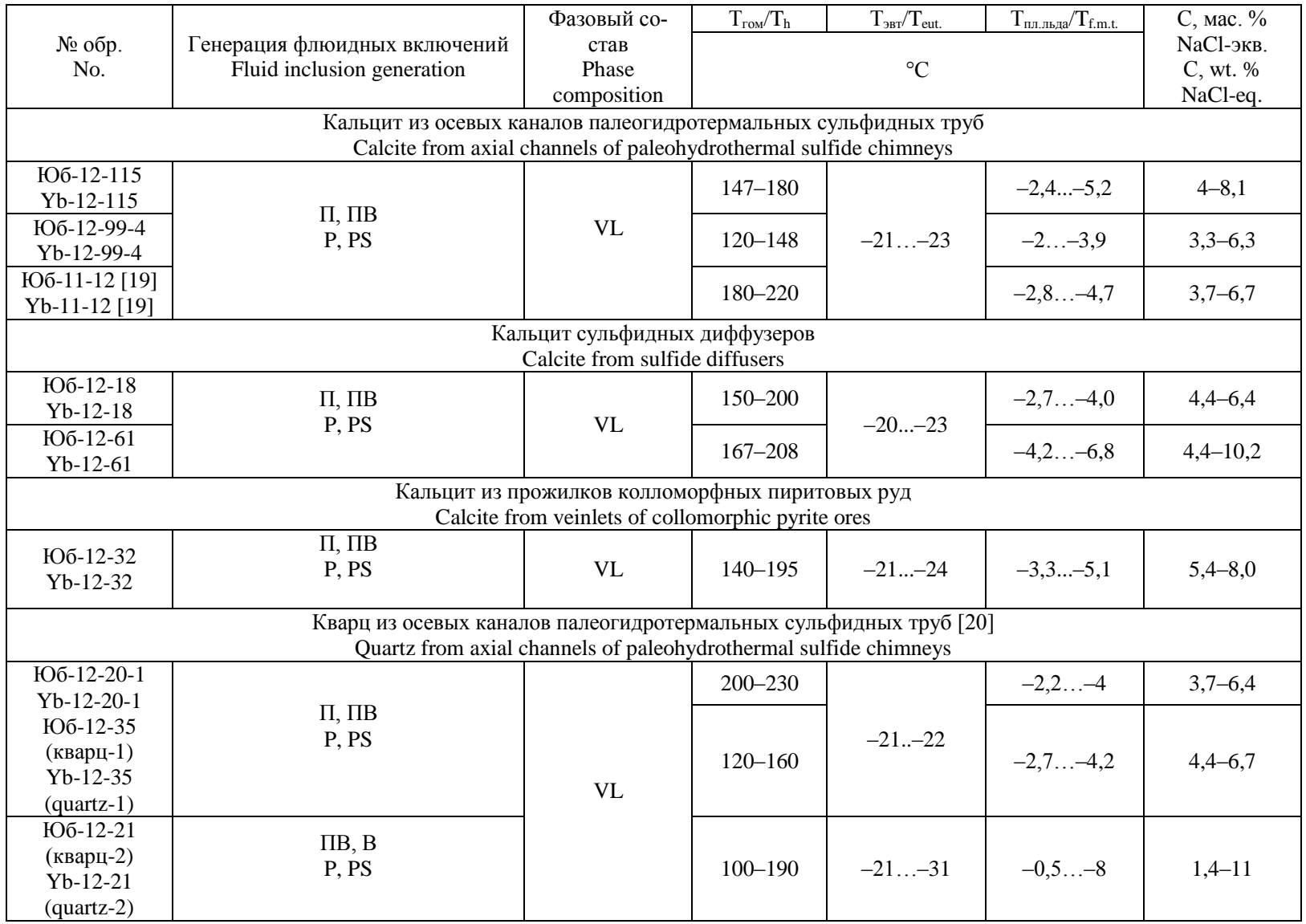

Примечание. Включения: П - первичные, ПВ - псевдовторичные, $B$ - вторичные; VL-двухфазные газово-жидкие.

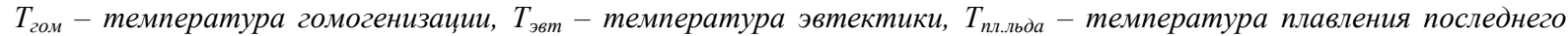
кристалла льда; С-соленость.

Note. Inclusions: $\Pi$ - primary, $\Pi B$ - pseudosecondary, B - secondary; VL-two-phased (gas-liquid). $T_{\text {гом }}$ - homogenization temperature, $T_{\text {эвт }}$ - eutectic temperature, $T_{\text {пллльда }}-$ final melting temperature; $C$ - salinity. 


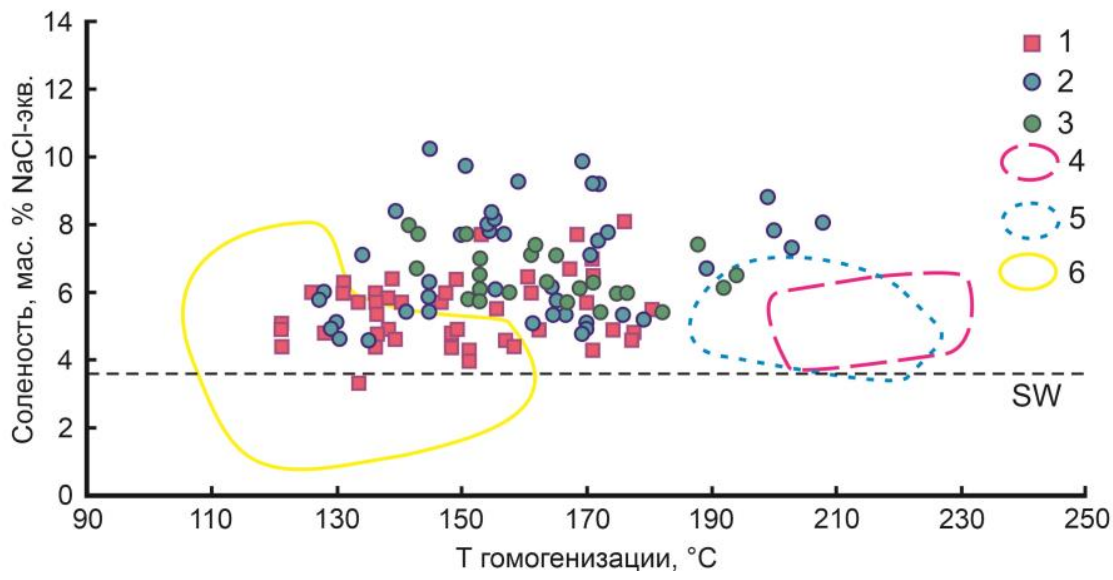

Рис. 4. Результаты исследований флюидных включений в кальците и кварие сульфидных руд Юбилейного месторождения: 1 - кальцит палеогидротермальных сульфидных труб (юб-12-99, юб-12-115); 2 - кальцит сульфидных диффузеров; 3 - прожилок кальцита в колломорфных пиритовых рудах. Флюидные включения в ранее изученных палеогидротермальных сульфидных трубах: 4 - кальцит; 5 - квари-1; 6 - квари-2 [19]. SW соленость морской воды при $25^{\circ} \mathrm{C}$

Fig. 4. Fluid inclusions data of calcite and quartz from sulfide ores of Yubileynoe VMS deposit: 1 - calcite from paleohydrothermal sulfide chimneys (юб-12-99, юб-12-115); 2 - calcite of sulfide diffusers; 3 - calcite veins in collomorphic massive sulfide ores. Previous fluid inclusions data of paleohydrothermal sulfide chimneys: 4 - calcite; 5 - quartz-1; 6 - quartz-2 [19]. SW-salinity of seawater at $25^{\circ} \mathrm{C}$

Для флюидных включений в кальците сульфидных

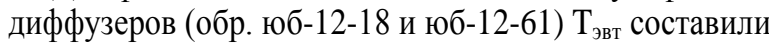
$-21 \ldots-23{ }^{\circ} \mathrm{C}$, что также свидетельствует о $\mathrm{Na}-\mathrm{K}$ хлоридном составе флюида. Температуры плавления последнего кристалла льда варьируют в диапазоне $-2,7 \ldots-6,8^{\circ} \mathrm{C}$, и соответствуют концентрациям флюида 4,4-10,2 мас. \% $\mathrm{NaCl}$-экв. Температуры гомогенизации в жидкую фазу варьируют от 122 до $208^{\circ} \mathrm{C}$ (мода $140-180^{\circ} \mathrm{C}$ ).

В прожилках кальцита колломорфных пиритовых руд (обр. юб-12-32) температуры эвтектики растворов флюидных включений $--21 \ldots-24{ }^{\circ} \mathrm{C}$ указывают на $\mathrm{Na}-\mathrm{K}$-хлоридный состав флюида. Концентрации солей, оцененные по температурам плавления льда $\left(-3,3 \ldots-5,1{ }^{\circ} \mathrm{C}\right)$, составили $5,4-8$ мас. \% NaCl-экв. Гомогенизация включений в жидкую фазу происходила при $141-194{ }^{\circ} \mathrm{C}$ (моды $140-145 ; 150-155 ; 160-175^{\circ} \mathrm{C}$ ).

По результатам рамановской спектроскопии флюидные включения в кварце палеогидротермальных труб заполнены преимущественно $\mathrm{CH}_{4}\left(2917 \mathrm{~cm}^{-1}\right)$ и $\mathrm{N}_{2}$ $\left(2331 \mathrm{~cm}^{-1}\right)$. Относительные концентрации $\mathrm{N}_{2}$ варьируют от 0 до 21,3 мол. $\%, \mathrm{CH}_{4}$ - от 78,7 до 100 мол. $\%$. В некоторых флюидных включениях $\mathrm{N}_{2}$ преобладает над $\mathrm{CH}_{4}$ (до 62-82 и 18-38 мол. \%, соответственно).

Значения $\delta^{13} \mathrm{C}$ и $\delta^{18} \mathrm{O}$ в кальците, выполняющем осевые каналы палеогидротермальных сульфидных труб, варьируют от $-3,71$ до $0,72 \%$ и от 8,82 до $21,31 \%$, соответственно (табл. 2, рис. 5). Величины $\delta^{13} \mathrm{C}$ в кальците сульфидных диффузеров составляют от $-3,57$ до $0,67 \%$, а $\delta^{18} \mathrm{O}$ - от 7,4 до $19,84 \%$; для кальцита прожилков в колломорфных пиритовых рудах $--1,22 \ldots 0,27 \% \delta^{13} \mathrm{C}$ и $15,39 \ldots 15,87 \% \delta^{18} \mathrm{O}$. Дополнительные изотопно-геохимические данные, полученные для кальцита сульфидных биоморфоз, обладают значениями $\delta^{13} \mathrm{C}(-1,41 \ldots-0,17 \%)$ и $\delta^{18} \mathrm{O}$ $(11,23 \ldots 13,76 \%)$
Таблица 2. Значения $\delta^{13} \mathrm{C} и \delta^{18} \mathrm{O}$ в кальците и равновесном с ним флюиде сульфидных построек и руд Юбилейного месторождения

Table 2. Values of $\delta^{13} \mathrm{C}$ and $\delta^{18} \mathrm{O}$ in calcite and equilibrium fluid of sulfide edifices and ores of Yubileynoe deposit

\begin{tabular}{|c|c|c|c|c|}
\hline $\begin{array}{l}\text { № oбразца } \\
\text { Sample no. }\end{array}$ & $\begin{array}{l}\delta^{13} \mathrm{C} \% \\
\text { VPDB }\end{array}$ & \begin{tabular}{|l}
$\delta^{18} \mathrm{O} \%$ \\
VSMOW
\end{tabular} & $\begin{array}{l}\delta^{13} \mathrm{C}_{\mathrm{CO} 2} \%, \\
\text { VPDB }\end{array}$ & $\begin{array}{l}\delta^{18} \mathrm{O}_{\mathrm{H} 20 \%} \% \\
\text { VSMOW }\end{array}$ \\
\hline \multicolumn{5}{|c|}{$\begin{array}{l}\text { Палеогидротермальные сульфидные трубы } \\
\text { Paleohydrothermal sulfide chimneys }\end{array}$} \\
\hline Юб-12-3x-1 & 0,65 & 21,31 & - & - \\
\hline Юб-12-7-2 & $-0,37$ & 17,3 & - & - \\
\hline Юб-12-15-1 & $-0,24$ & 19,07 & - & - \\
\hline Юб-11-63 & $-3,71$ & 8,82 & - & - \\
\hline Юб-12-64 & $-0,09$ & 18,82 & $\begin{array}{llll}- & \\
\end{array}$ & - \\
\hline Юб-12-76 & 0,46 & 15,83 & - & - \\
\hline Юб-12-94 & $-1,0$ & 16,12 & - & - \\
\hline Юб-12-97 & $-1,41$ & 12,66 & - & - \\
\hline Юб-12-99 & 0,94 & 12,45 & $-2,6$ & 2,82 \\
\hline Юб-12-105-1 & $-0,21$ & 13,69 & - & - \\
\hline Юб-12-105-2 & 0,72 & 21,61 & - & - \\
\hline Юб-12-114 & 0,18 & 15,97 & - & - \\
\hline Юб-12-115 & $-0,22$ & 19,33 & $-0,62$ & 8,33 \\
\hline \multicolumn{5}{|c|}{$\begin{array}{c}\text { Сульфидные диффузоры (ажурные серноколчеданные руды) } \\
\text { Sulfide diffusers (reniform pyrite ores) }\end{array}$} \\
\hline Юб-16-2 & $-1,89$ & 7,4 & - & - \\
\hline Юб-12-3x-2 & 0,23 & 19,84 & - & - \\
\hline Юб-11-11 & $-0,96$ & 19,81 & - & - \\
\hline Юб-12-18 & $-3,57$ & 13,25 & 3,17 & 2,25 \\
\hline Юб-11-61 & $-0,95$ & 12,53 & $-0,55$ & 3,23 \\
\hline Юб-11-61-1 & 0,67 & \begin{tabular}{|l|}
10,73 \\
\end{tabular} & 1,07 & 1,43 \\
\hline \multicolumn{5}{|c|}{$\begin{array}{c}\text { Кальцит сульфидных биоморфоз } \\
\text { Calcite of sulfide biomorphoses }\end{array}$} \\
\hline Юб-11-23 & $-0,17$ & 13,76 & - & - \\
\hline Юб-11-25 & $-1,41$ & 11,23 & - & - \\
\hline Юб-11-25-1 & $-0,92$ & 13,39 & - & $\begin{array}{llll}- & & & \end{array}$ \\
\hline \multicolumn{5}{|c|}{$\begin{array}{c}\text { Прожилки кальцита в колломорфных пиритовых рудах } \\
\text { Calcite veins in collomorphic pyrite ores }\end{array}$} \\
\hline Юб-11-32 & 0,27 & 15,87 & 0,27 & 5,67 \\
\hline Юб-11-32-1 & $-1,22$ & 15,39 & $-1,22$ & 5,19 \\
\hline
\end{tabular}




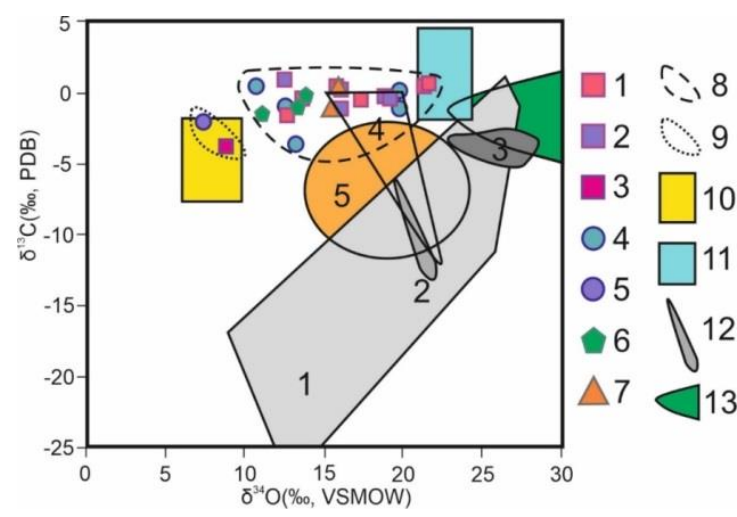

Puc. 5. Значения $\delta^{13} \mathrm{C}$ и $\delta^{18} \mathrm{O}$ кальичта реликтов сульфидных труб, диффузеров, биоморфоз и колломорфных руд Юбилейного месторождения: 1-3 - палеогидротермальные сульфидные трубы: 1 - кальичт-пирит-халькопиритовые, 2 - кальцитсфалерит-пирит-халькопиритовые, 3 - тальккальциит-халькопирит-пирит-сфалеритовые; 4, 5 сульфидные диффузоры: 4 - пиритовые и халькопирит-пиритовые; 5 - пирит-сфалеритовые; 6 - сульфидные биоморфозы; 7 - прожилки кальиита в колломорфных пиритовых рудах; 8 кальиит сульфидных труб и диффузеров в ассоииачии с пиритом и халькопиритом; 9 - кальцит сульфидных труб и диффузеров в ассочииаиии со сфалеритом; 10 - магматический флюид [31]; 11 - морские известняки [32-34]; 12, 13 - поля изотопного состава карбонатов: 12 - колчеданных месторождений Урала*; 13 - современных океанических базальтов [34-36]. *Колчеданные месторождения: 1 - Узельгинское; 2 - Сафьяновское; 3 - Александринское; 4 - Талганское; 5 - Иберийского пояса [32, 36-39]

Fig. 5. Values of $\delta^{13} C$ and $\delta^{18} O$ of calcite from sulfide chimneys relics, diffusers, biomorphoses and collomorphic ores of Yubileynoe deposit: 1-3 - paleohydrothermal sulfide chimneys: 1 - calcite-pyritechalcopyrite, 2 - calcite-sphalerite-pyritechalcopyrite, 3 - talc-calcite-chalcopyrite-pyritesphalerite; 4, 5 - sulfide diffusers: 4 - pyrite and chalcopyrite-pyrite; 5 - pyrite-sphalerite; 6 -sulfide biomorphoses; 7 - calcite veins in collomorphic pyrite ores; 8 - calcite in sulfide chimneys and diffusers associated with pyrite and chalcopyrite; $9-$ calcite of sulfide chimneys and diffusers associated with sphalerite; 10 - magmatic fluid [31]; 11 - marine limestones [32-34]; 12, 13 - fields of isotopic composition of carbonates: $12-V M S$ deposits of the Urals*; 13 - modern oceanic basalts [38-40]. *VMS deposits: 1 -Uzelga; 2 - Safyanovka; 3 -Alexandrinskoe; 4 - Talgan; 5 - Iberian belt [32, 36-39]

Значения $\delta^{13} \mathrm{C}_{\text {СО2 }}$ флюида сульфидных труб в равновесии с кальцитом составляют $-2,6 \ldots-0,6 \%$ при $148-180{ }^{\circ} \mathrm{C}$ (рис. 6). Величины $\delta^{13} \mathrm{C}_{\mathrm{CO} 2}(-0,5 \ldots 3,1 \%)$ в кальците сульфидных диффузеров рассчитаны для $179-208{ }^{\circ} \mathrm{C}$. Значения $\delta^{13} \mathrm{C}_{\mathrm{CO} 2}(-1,2 \ldots 0,2 \%)$ флюида кальцитовых прожилков в колломорфных пиритовых рудах подсчитаны для $193{ }^{\circ} \mathrm{C}$. Рассчитанные изотопные данные $\delta^{13} \mathrm{C}_{\mathrm{CO} 2}$ флюида попали в интервалы изотопных соотношений углерода морских карбонатов $(-2,0 \ldots 6,0 \%$ [40]) и морской воды $(-5 \ldots 4 \%[41,42])$.
Расчетные величины $\delta^{18} \mathrm{O}_{\text {H2о }}$ флюида для 148 и $180{ }^{\circ} \mathrm{C}$ сульфидных труб варьируют в пределах $2,82 \ldots 8,53 \%$ (рис. 6). Значения $\delta^{18} \mathrm{O}_{\text {н2о }}$ флюида сульфидных диффузеров при $179-208{ }^{\circ} \mathrm{C}$ составили $1,43 \ldots 3,23 \%$ \%. Изотопный состав воды флюида прожилков кальцита при $193{ }^{\circ} \mathrm{C}$ равен 5,19...5,67\% \%. Большая

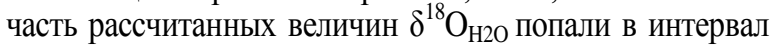
значений, характерных для метеорной воды $(-40 \ldots .5,5 \%$ \% [43]. Единичные пробы кальцита сульфидных труб и прожилков в колломорфных рудах соответствуют величинам $\delta^{18} \mathrm{O}_{\text {н20 }}$ магматической воды [43].

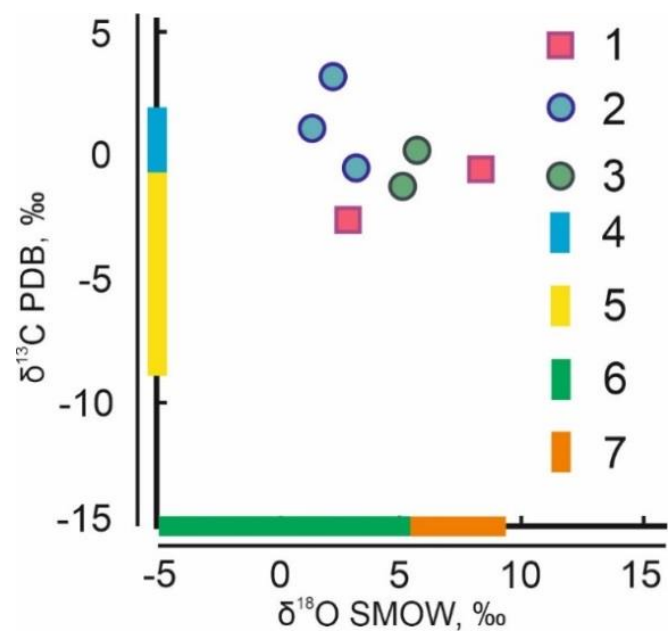

Pис. 6. Значения $\delta^{13} \mathrm{C}$ и $\delta^{18} \mathrm{O}$ флюида, отложившего кальиит сульфидных руд Юбилейного месторождения: 1 - палеогидротермальные сульфидные трубы; 2 - сульфидные диффузоры; 3 прожилки кальиита колломорфных руд; изотопные составы: 4 - углерода морских известняков; 5 - углерода магматического или глубинного корового флюида; 6 - кислорода метеорной воды; 7 - кислорода магматической воды [43-46]

Fig. 6. Values of $\delta^{13} C$ and $\delta^{18} O$ of calcite-forming fluid of sulfide ores of Yubileynoe VMS deposit: 1 -paleohydrothermal sulfide chimneys; 2 - sulfide diffusers; 3 - calcite veins in collomorphic ores; isotopic compositions: 4 - carbon of marine limestone; 5 - carbon of magmatic or crustal fluid; 6 - oxygen of meteoric water; 7 - oxygen of magmatic water [43-46]

\section{Обсуждение результатов}

По результатам термобарогеохимических исследований гомогенизация флюидных включений в кальците реликтов донных палеогидротермальных сульфидных построек (сульфидные трубы, диффузеры и биоморфозы) происходила в температурном интервале от 120 до $210{ }^{\circ} \mathrm{C}$. Моды значений $\mathrm{T}_{\text {гом вклю- }}$ чений в кальците: палеогидротермальных труб $135-140$ и $160-180{ }^{\circ} \mathrm{C}$; сульфидных диффузеров $140-160{ }^{\circ} \mathrm{C}$. Флюидные включения в кальците прожилков колломорфных руд гомогенизировались при 140-190 ${ }^{\circ} \mathrm{C}$. Температуры гомогенизации оказались ниже, чем полученные ранее $\mathrm{T}_{\text {гом }}$ для кальцита $\left(200-220^{\circ} \mathrm{C}\right)$ и кварца из осевых каналов $\left(215-225^{\circ} \mathrm{C}\right)$ палеогидротермальных труб, и сопоставимы с данными для позднего кварца-2 $\left(120-140{ }^{\circ} \mathrm{C}\right)$ (табл. 1) [19]. Температуры гомогенизации флюидных вклю- 
чений в кальцит-сфалерит-пирит-халькопиритовых трубах согласуются с температурами образования ассоциирующего с кальцитом сфалерита (149-243 $\left.{ }^{\circ} \mathrm{C}\right)$, полученными с помощью эмпирического $\mathrm{Ga}-\mathrm{Ge}$ геотермометра GGIMFis [47].

Большая часть полученных $\mathrm{T}_{\text {гом }}$ ниже непосредственно измеренных температур флюидов на современных гидротермальных источниках дна океана $\left(260-380{ }^{\circ} \mathrm{C}\right)$ и данных гомогенизации флюидных включений в минералах современных построек в задуговых бассейнах $\left(150-385^{\circ} \mathrm{C}\right)$ [48]. Температуры гомогенизации флюидных включений в кальците палеогидротермальных труб, сульфидных диффузеров и прожилков в колломорфных пиритовых рудах попадают в интервал, характерный для тонкозернистых и колломорфных руд $\left(130-215{ }^{\circ} \mathrm{C}\right)$ колчеданных месторождений Верхнеуральского, Учалинского и Александринского рудных районов $[1,4,6]$. Отмечается, что в рудах колчеданных месторождений Южного Урала температуры гомогенизации флюидных включений в нерудных минералах не связаны с минеральным составом, а зависят от текстурно-структурных особенностей руд, обусловленных диагенетическими и эпигенетическими преобразованиями $[1,4]$. Гомогенизация флюидных включений в сфалерите, кварце, барите и кальците, запечатывающих палеогидротермальные трубы на Яман-Касинском и Александринском месторождениях, происходила при температуpax от 110 до $250{ }^{\circ} \mathrm{C}$, с преобладанием значений 150-180 ${ }^{\circ} \mathrm{C}$ [7, 49, 50]. Сопоставимые температуры гомогенизации включений в прозрачных минералах реликтов палеогидротермальных труб (135-140; 160-180 $\left.{ }^{\circ} \mathrm{C}\right)$, сульфидных диффузеров $\left(140-160{ }^{\circ} \mathrm{C}\right)$ и кальцитовых прожилков в колломорфных колчеданных рудах $\left(140-190{ }^{\circ} \mathrm{C}\right.$.) на Юбилейном и других колчеданных месторождениях Южного Урала могут быть объяснены схожими условиями эпигенетических процессов и, вероятно, завершают или следуют за процессами колчеданонакопления. При этом участие в сульфидонакоплении низкотемпературных растворов $\left(\leq 170{ }^{\circ} \mathrm{C}\right)$, наравне с высокотемпературными (до $\left.355^{\circ} \mathrm{C}\right)$, описано для гидротермальных полей Ашадзе и Логачев [13]. Исходя из этого, можно предположить, что температуры, определенные для кварца $\left(215-225^{\circ} \mathrm{C}\right)$ и кальцита осевых каналов труб (200$220^{\circ} \mathrm{C}$ ) в сочетании с включениями ориентированных агрегатов сульфидов в них, могут быть свидетельством образования этих нерудных минералов во время относительно низкотемпературных стадий первичного колчеданообразования.

Концентрация солей во флюидных включениях в кальците составляет 3,3-10,2 мас. \% NaCl-экв. с пиком 4-7 мас. \% NaCl-экв., при отсутствии разбавленных флюидов (<3 мас. \%) во включениях в низкотемпературном позднем кварце. Аналогичная соленость (4-6 мас. \% NaCl-экв.) сообщается для многих современных сульфидных гидротермальных построек [5153]. Возрастание солености может быть связано с взаимодействием флюида с породами реакционной зоны, конвекции нагретых вод и/или его вскипанием [29, 54, 55]. Другой причиной повышения солености флюида могло стать участие высококонцентрированного магматического флюида [56]. Одновременное присутствие однофазных газовых и жидкостных, двухфазных газово-жидких включений с различной концентрацией солей может указывать на возможную фазовую сепарацию флюида [19].

По данным рамановской спектроскопии основными летучими компонентами флюида являются $\mathrm{H}_{2} \mathrm{O}$, $\mathrm{CH}_{4}$ и $\mathrm{N}_{2}$. Концентрации метана фиксируются во флюидах и гидротермальных плюмах современных сульфидных полей, связанных с ультраосновными породами и характерны для труб «черных курильщиков» Срединно-Атлантического хребта [57]. Однако в то же время присутствие $\mathrm{CH}_{4}$ может быть связано с восстановлением $\mathrm{CO}_{2}$ [58].

Примесь марганца (до 1,12 мас. \%) в кальците палеогидротермальных труб может быть связана с особенностями состава колчеданообразующих флюидов и приурочена ко времени отложения рудных ассоциаций $[2,59]$.

Изученный кальцит характеризуется широкими вариациями изотопного состава $\delta^{13} \mathrm{C}$ и $\delta^{18} \mathrm{O}$, что может указывать на смешанную природу минералообразующего флюида (рис. 5). Кальцит сульфидных труб и диффузеров в ассоциации с пиритом и халькопиритом имеет более легкий изотопный состав кислорода $(10,71 \ldots 21,61 \%)$ и углерода $(-3,71 \ldots 0,72 \%)$ по сравнению с морскими известняками. В то же время кальцит, связанный с существенно сфалеритовыми реликтами сульфидных труб и диффузеров, обладает наиболее легким изотопным составом $\delta^{18} \mathrm{O}$ $(7,4 \ldots 8,82 \%)$ и попадает в область значений магматического флюида. Облегчение изотопного состава $\delta^{18} \mathrm{O}$ и $\delta^{13} \mathrm{C}$ существенно сфалеритовых труб и диффузеров может быть связано с кипением флюида, при котором тяжелые изотопы углерода и кислорода удалялись, однако такое фракционирование может изменить значения $\delta^{13} \mathrm{C}$ не более чем на $1 \%$ [29, 31, 60]. Расчетные величины $\delta^{18} \mathrm{O}_{\mathrm{H} 2 \mathrm{O}}$ и $\delta^{13} \mathrm{C}_{\mathrm{CO} 2}$ флюида также свидетельствуют о смешанном магматогеннометеорном происхождении флюида (рис. 5).

По сравнению с другими колчеданными месторождениями Южного Урала изученный кальцит Юбилейного месторождения характеризуется более легким изотопным составом углерода и кислорода (рис. 5). Разброс значений $\delta^{18} \mathrm{O}$ в прожилках и гнездах кальцита руд Сафьяновского $(19,8 \ldots 21,2$ \%о) и Александринского $(22,9 . .28,2$ \%о) месторождений меньше, чем на Юбилейном $(7,4 \ldots 21,31 \%)$ [32]. Кальцит Узельгинского и Талганского колчеданных месторождений на Южном Урале и объектов Иберийского пиритового пояса характеризуется более легким $\delta^{13} \mathrm{C}$ по сравнению с исследованными образцами Юбилейного месторождения [32, 36-39]. Относительно легкий изотопный состав $\delta^{13} \mathrm{C}$ колчеданных месторождений и современных гидротермальных полей $(-4 \ldots-7 \%$ \%) интерпретируется как свидетельство глубинного источника углерода [61].

Полученные данные указывают на то, что основным источником углерода кальцита являлся бикарбо- 
нат морской воды, который смешан с магматическим флюидом, обусловившим пониженные значения $\delta^{13} \mathrm{C}$. Смешанное ювенильно-морское происхождение гидротермальных флюидов предполагается и для других колчеданных объектов Урала [32]. Изотопный состав кислорода кальцита может резко изменяться в одном образце и близких минеральных ассоциациях, например, в кальцит-пирит-халькопиритовых палеогидротермальных трубах вариации $\delta^{18} \mathrm{O}$ составляют 12,66 $21,61 \%$ (в среднем 17,3 \%о). Это может являться свидетельством того, что постседиментационные процессы не привели к гомогенизации изотопного состава кислорода.

Смешанный источник флюида, изотопный состав которого обусловлен поступлениями как магматической, так и морской воды, может быть подтвержден данными изотопного состав серы $\delta^{34} \mathrm{~S}$ гидротермального пирита сульфидных труб. Источником серы для формирования сульфидов могли быть базальты (0-1 \%0, [62]) и морская вода в раннем девоне $(+18-23 \%$, [63]). Количество морской воды в рудообразующем флюиде может быть оценено по формуле [62, 64]:

$$
\delta^{34} \mathrm{~S}_{\mathrm{mix}}=\mathrm{X} \times \delta^{34} \mathrm{~S}_{\text {морская вода }}+(1-\mathrm{X}) \times \delta^{34} \mathrm{~S}_{\text {баз. }},
$$

где $\mathrm{X}$ - количество морской воды во флюиде; изотопные составы серы $\delta^{34} \mathrm{~S}_{\mathrm{mix}}$ - пирита, $\delta^{34} \mathrm{~S}_{\text {морская вода }}-$ морской воды, $\delta^{34} \mathrm{~S}_{\text {баз. }}-$ базальта. Изотопный состав $\delta^{34} \mathrm{~S}$ пирита варьирует от $+0,58$ до $+2,02 \%$ [17], что соответствует смешению 2-11\% серы морской воды и 89-98 \% серы вмещающих базальтов.

Таким образом, образование кальцита и кварца реликтов палеогидротермальных труб с $\mathrm{T}_{\text {гом }}$ флюидных включений $>200{ }^{\circ} \mathrm{C}$ каналов происходило одновременно с агрегатами талька и сульфидов. Прожилки карбонатов $\left(\mathrm{T}_{\text {гом }} 140-190{ }^{\circ} \mathrm{C}\right.$.) в тонкозернистых колчеданных рудах, вероятно, связаны с трещинами скалывания и отрыва, в которых не происходило сульфидообразования. По-видимому, температуры гомогенизации флюидных включений в подавляющем большинстве агрегатов кальцита сульфидных диффузеров и палеогидротермальных труб отражают условия диагенеза колчеданных руд. Принимая во внимание глубину отложения современных сульфид-

\section{СПИСОК ЛИТЕРАТУРЫ}

1. Карпухина В.С., Баранов Э.Н. Физико-химические условия формирования колчеданных месторождений Верхнеуральского района, Южный Урал // Геохимия. - 1995. - № 1. - С. 48-63.

2. Марганец - индикатор условий образования карбонатов на колчеданных медно-цинковых месторождениях Южного Урала (Россия) / С.Л. Вотяков, В.В. Масленников, Д.Р. Борисов, А.А. Краснобаев // Геология рудных месторождений - 1996. Т. 38. - № 6. - C. 558-569.

3. Викентьев И.В. Условия формирования и метаморфизм колчеданных руд. - М.: Научный мир, 2004. - 322 с.

4. Карпухина В.С., Наумов В.Б., Викентьев И.В. Генезис колчеданных месторождений Верхнеуральского рудного района (Южный Урал, Россия): свидетельства магматического вклада металлов и флюида // Геология рудных месторождений. 2013. - T. 55. - № 2. - C. 145-165.

5. Физико-химические исследования карбонатов Сафьяновского медно-колчеданного месторождения (Средний Урал) / Е.И. Сорока, М.Е. Притчин, В.П. Лютоев, И.В. Смолева // Вестник Пермского Университета. Геология. - 2019. - Т. 18. № 2. - C. $152-164$. ных построек «черных курильщиков» в 2500 м и давление около 250 бар [49], истинные температуры образования исследованных агрегатов кальцита и кварца составляют $140-220{ }^{\circ} \mathrm{C}$.

\section{Заключение}

Гомогенизация флюидных включений в изученном кальците и кварце происходила в интервале $120-225^{\circ} \mathrm{C}$, соленость водного раствора - 3,3-10,2 мас. \% $\mathrm{NaCl}$-экв. Значительная часть флюидных включений $\left(\mathrm{T}_{\text {гом }}<200{ }^{\circ} \mathrm{C}\right)$ в прозрачных минералах реликтов палеогидротермальных труб, сульфидных диффузеров и кальцитовых прожилков в колломорфных колчеданных рудах на Юбилейном медноколчеданном месторождении, вероятно, связана с эпигенетическими процессами преобразования колчеданных руд. Флюидные включения в кварце и кальците с $\mathrm{T}_{\text {гом }}>200{ }^{\circ} \mathrm{C}$ могли образоваться во время относительно низкотемпературных стадий первичного колчеданообразования.

Изотопный состав $\delta^{13} \mathrm{C}$ и $\delta^{18} \mathrm{O}$ изученного кальцита, а также расчетные величины $\delta^{18} \mathrm{O}_{\mathrm{H} 2 \mathrm{O}}$ и $\delta^{13} \mathrm{C}_{\mathrm{CO} 2}$ флюида свидетельствуют о его двойственном происхождении, предполагающем смешение морской воды и магматического флюида.

По температурам гомогенизации и солевому составу флюиды кальцита и кварца сульфидных труб и диффузеров Юбилейного месторождения близки к прозрачным минералам, запечатывающим палеогидротермальные трубы колчеданных залежей Яман-Касы и Александринское, а также температурам гидротермальных растворов современных сульфидных построек.

Авторы выражают благодарность научным сотрудникам ЮУ ФНЦ МиГ УрО РАН чл. корр. РАН Валерию Владимировичу Масленникову за помощь в подготовке статьи и представленный каменный материал, к.г-м.н. Михаилу Владимировичу Штенбергу и д.г-м.н. Ивану Александровичу Блинову за проведение аналитических работ, а также Сергею Захаровичу Смирнову (ИГМ СО РАН, г. Новосибирск) за предоставленную возможность изучения флюидных включений методом рамановской спектроскопии. Исследования выполнены в рамках госбюджетной темы ЮУ ФНЦ МиГ УрО РАН № АААА-А19-119061790049-3.

6. Роль магматического флюида в формировании Талганского медно-цинково-колчеданного месторождения, Южный Урал / Е.Е. Амплиева, И.В. Викентьев, В.С. Карпухина, Н.С. Бортников // Доклады Академии Наук. - 2008. - Т. 423. - № 4. С. 516-519

7. Масленникова С.П., Масленников В.В. Сульфидные трубы палеозойских «чёрных курильщиков» (на примере Урала). Екатеринбург; Миасс: УрО РАН, 2007. - 312 с.

8. Масленников В.В., Масленникова С.П., Леин А.Ю. Минералогия и геохимия древних и современных черных курильщиков. - М.: РАН, 2019. - 832 c.

9. Минерального-геохимические особенности сульфидных труб Юбилейного медноколчеданного месторождения (Южный Урал) / А.С. Целуйко, В.В. Масленников, С.П. Масленникова, Л.В. Данюшевский, В.А. Котляров, И.А. Блинов // Минералогия. - 2019. - № 4. - С. 52-72.

10. Chimneys in Paleozoic massive sulfide mounds of the Urals VMS deposits: Mineral and trace element comparison with modern black, grey, white and clear smokers / V.V. Maslennikov, S.P. Maslennikova, R.R. Large, L.V. Danyushevsky, R.J. Herrington, N.R. Ayupova, V.V. Zaykov, A.Yu. Lein, A.S. Tseluyko, 
I.Yu. Melekestseva, S.G. Tessalina // Ore Geology Reviews. 2017. - V. 85. - P. 64-106.

11. Гидротермальные сульфидные руды и металлоносные осадки океана / С.Г. Краснов, Г.А. Черкашев, А.И. Айнемер, Э.Ф. Гринталь, Д.В. Гричук, М.П. Давыдов, И.М. Порошина, Т.В. Степанова, С.М. Судариков, Л.И. Бочек, В.А. Даценко, Е.П. Дубинин, Е.А. Ельянова, Н.М. Заири, О.В. Колосов, Ю.В. Миронов, В.Е. Попов, И.А Андреева., П.А. Ваганов, Н.Е. Герман, Н.И. Гуревич, И.И. Крейтер, М.Н. Маслов. СПб: Недра, 1992. - 278 с.

12. Гидротермальный рудогенез океанского дна / Ю.А. Богданов, А.П. Лисицын, А.М. Сагалевич, Е.Г. Гурвич. - М.: Наука, 2006. $-527 \mathrm{c}$.

13. Физико-химические условия гидротермальных рудообразующих систем «черных курильщиков», ассоциирующих с мантийными гипербазитами в Центральной Атлантике Н.С. Бортников, В.А. Симонов, Е.Е. Амплиева, О.О. Ставрова, И. Фуке // Геология и геофизика. - 2011. -Т. 52. - № 11. C. $1790-1801$.

14. Rona P.A., Widenfalk L., Bostrom K. Serpentinized ultramafics and hydrothermal activity at the Mid-Atlantic Ridge crest near $15^{\circ} \mathrm{N} / /$ Journal of Geophysical Research: Solid Earth. - 1987. - V. 92 . Iss. B2. - P. 1417-1427.

15. The minor element endowment of modern sea-floor massive sulfides and comparison with deposits hosted in ancient volcanic successions / T. Monecke, S. Petersen, M.D. Hannington, H. Grant, I.M. Samson // Economic Geology. - 2016. - V. 18. - № 8. P. 245-306.

16. Effects of fluid boiling on Au and volatile element enrichment in submarine arc-related hydrothermal systems / J.J. Falkenberg, M. Keith, K.M. Haase, W. Bach, R. Klemd, H. Strauss, I.A. Yeo, K.H. Rubin, B. Storch, M.O. Anderson // Geochimica et Cosmochimica Acta. - 2021. - V. 307. - P. 105-132.

17. Изотопный состав серы сульфидов продуктов разрушения палеокурильщиков Юбилейного медноколчеданного месторождения (Южный Урал) / А.С. Целуйко, В.В. Масленников, Н.Р. Аюпова, С.А. Садыков // Минералогия. - 2015. - № 4. C. $103-111$.

18. Целуйко А.С., Анкушева Н.Н. Условия формирования труб «палеокурильщиков» Юбилейного медноколчеданного месторождения (Южный Урал) по данным термобарогеохимии и КР-спектроскопии // Металлогения и современных океанов2016. - Миасс: Институт минералогии УрО РАН, 2016. C. 101-106.

19. Анкушева Н.Н., Целуйко А.С., Штенберг М.В. Условия формирования Юбилейного месторождения (Южный Урал) по данным термобарогеохимии и колебательной спектроскопии Наука ЮУрГУ: Материалы 68-й научной конференции Секции естественных наук. - Челябинск: ЮУРГУ, 2016. - С. 239-247.

20. Косарев А.М. О результатах разработки моделей рудномагматических систем девонских колчеданоносных вулканических комплексов Магниторской островодужной мегазоны, Южный Урал // Металлогения древних и современных океанов-2021. - Миасс: Институт минералогии УрО РАН, 2021. C. $10-12$.

21. Бонинитовые вариолиты Бурибайского вулканического комплекса Южного Урала: минералогия, геохимия и условия образования / А.М. Косарев, С.А. Светов, С.Ю. Чаженгина, Г.Т. Шафигуллина // Литосфера. - 2018. - Т. 18. - № 2. C. 246-279.

22. Воробьев В.В., Попов Е.В., Сапонов А.В., Антошкин Д.М., Попова Л.П. Отчет о детальной разведке Юбилейного медноколчеданного месторождения на Южном Урале в 1969-73 гг. Бурибай, Переволочанская геологоразведочная экспедиция. T. 1. $-1973 .-351 \mathrm{c}$

23. The history of life at hydrothermal vent / M.N. Georgieva, C.T.S. Little, V.V. Maslennikov, A.G. Glover, N.R. Ayupova, R.J. Herrington // Earth-Science Reviews. - 2021. - V. 217. P. $1-21$.

24. Борисенко А.С. Изучение солевого состава растворов газовожидких включений в минералах методом криометрии // Геология и геофизика. -1977 . - № 8. - С. 16-28.

25. Davis D.W., Lowenstein T.K., Spenser R.J. Melting behavior of fluid inclusions in laboratory-grown halite crystals in the systems $\mathrm{NaCl}-\mathrm{H}_{2} \mathrm{O}, \mathrm{NaCl}-\mathrm{KCl}-\mathrm{H}_{2} \mathrm{O}, \mathrm{NaCl}-\mathrm{MgCl}_{2}-\mathrm{H}_{2} \mathrm{O}$ and $\mathrm{CaCl}_{2}-\mathrm{NaCl}-$
$\mathrm{H}_{2} \mathrm{O} / /$ Geochimica Et Cosmochimica Acta. - 1990 - V. 54 (3) P. 591-601.

26. Spenser R.J., Moller N., Weare J.N.The prediction of mineral solubilities in mineral waters: a chemical equilibrium model for the $\mathrm{Na}-\mathrm{K}-\mathrm{Ca}-\mathrm{Mg}-\mathrm{Cl}-\mathrm{SO}_{4}$ system at temperatures below $25^{\circ} \mathrm{C} / / \mathrm{Geo}-$ chimica Et Cosmochimica Acta. - 1990 - V. 54 (3) - P. 575-590.

27. Bodnar R.J., Vityk M.O. Interpretation of microthermometric data for $\mathrm{H} 2 \mathrm{O}-\mathrm{NaCl}$ fluid inclusions // Fluid inclusions in minerals: methods and applications. - Virginia Tech, Blacksburg, VA, 1994. - P. 117-130.

28. Burke E.A.J. Raman microspectrometry of fluid inclusions // Lithos. - 2001. - V. 55. - № 1. - P. 139-158.

29. Ohmoto H., Rye R.O. Isotopes of sulfur and carbon // Geochemistry of hydrothermal ore deposits / Ed. by H.L. Barner. - New York: Wiley, 1979. - P. 509-567.

30. Знаменский С.Е., Анкушева Н.Н. Большекаранское и Николаевское золоторудные месторождения (Южный Урал): флюидные включения, элементы-примеси и стабильные изотопы S, С и О в минералах рудных жил // Металлогения древних и современных океанов-2019. - Миасс: Институт минералогии УрO РAH, 2019. - C. 160-163.

31. Bowman J.R. Stable isotope systematic of skarns // Mineralized intrusion-related Skarn systems / Ed. by D.R. Lentz. - Canada: Mineralogical Association of Canada Short Course Series, 1998. P. 99-146.

32. Викентьев И.В. Условия формирования и метаморфизм колчеданных руд. - М.: Научный мир, 2004. - 322 c.

33. Veizer J., Hoefs J. The nature of $\mathrm{O}^{18} / \mathrm{O}^{16}$ and $\mathrm{C}^{13} / \mathrm{C}^{12}$ secular trends in sedimentary carbonate rocks // Geochimica et Cosmochimica Acta. - 1976. - V. 40. - P. 1387-1395.

34. Kerrich R. Carbon-isotope systematics of Archean Au-Ag vein deposit in the Superior Province // Canadian Journal Earth Science. - 1990. - V. 27. - P. 40-56.

35. Минералого-геохимические особенности гидротермальных сульфидных руд поля Рейнбоу, ассоциированного с серпентинитами, САХ ( $36^{\circ} 4^{\prime}$ с.ш.) / Ю.А. Богданов, Н.С. Бортников, И.В. Викентьев, А.Ю. Леин, Е.Г. Гурвич, А.М. Сагалевич, В.А. Симонов, С.В. Икорский, О.О. Ставрова, В.Н. Аполлонов // Геология рудных месторождений. - 2002. - Т. 44. - № 6. C. $510-542$.

36. Амплиева Е.Е. Геологическое строение, минералогогеохимические особенности и условия образования Талганского колчеданного месторождения, Южный Урал: автореф. дис. ... канд. геол.-минерал. наук. - М., 2008. - 38 с.

37. Tornos F., Gonza'lez-Clavijo E., Spiro B. The Filo'n Norte orebody (Tharsis, Iberian Pyrite Belt): a proximal low-temperature shale-hosted massive sulphide in a thin-skinned tectonic belt // Mineralium Deposita. - 1998. - V. 33. - P. 150-169.

38. Relvas J.M.R.S. Geology and metallogenesis at the Neves Corvo deposit, Portugal. PhD Thesis. - Portugal, 2000. - $319 \mathrm{p}$.

39. Source and evolution of ore-forming hydrothermal fluids in the northern Iberian Pyrite Belt massive sulphide deposits (SW Spain): evidence from fluid inclusions and stable isotopes / J. SanchezEspana, F. Velasco, A.J. Boyce, A.E. Fallick // Mineralium. Deposita. - 2003. - V. 38. - P. 519-537.

40. McCuaig T.C., Kerrich R. P-T-t-deformation-fluid characteristics of lode gold deposits: evidence from alteration systematics // Ore Geology Reviews. - 1998. - V. 12. - P. 381-453.

41. Sheppard S.M.H. Characterization and isotopic variations in natural waters // Stable isotopes in high temperature geological processes / Eds. J.W. Valley, H.P. Taylor, J.R. O'Neil. - Berlin: De Gruyter, 1986. - V. 16. - P. 165-183.

42. Valley J.W. Stable isotope geochemistry of metamorphic rocks // Stable isotopes in high temperature geological processes. Review Mineral / Eds. J.W. Valley, H.P. Taylor, J.R. O’Neil. - Berlin: De Gruyter, 1986. - V. 16. P. 445-489.

43. Rollinson H.R. Using geochemical data: evaluation, presentation, interpretation. - London, Longman Scientific and Technical, 1993. $-352 \mathrm{p}$

44. Знаменский С.Е., Анкушева Н.Н., Знаменская Н.М. Термобарогеохимические параметры и изотопный состав руд золотопорфирового месторождения Большой Каран (Южный Урал) // Геология, полезные ископаемые и проблемы геоэкологии Башкортостана, Урала и сопредельных территорий. - Уфа: ИГ УНЦ РАН, 2018. - С. 245-248. 
45. Omoto H., Goldhaber M.B. Sulfur and carbon isotopes // Geochemistry of hydrothermal ore deposits. - N.Y.: John Wiley and Sons, 1997. - P. 517-611.

46. Hoefs J. Stable isotope geochemistry. $6^{\text {th }}$ ed. - Berlin; Heidelberg: Springer-Verlag, 2009. $-285 \mathrm{p}$.

47. Целуйко А.С., Артемьев Д.А. Применение Ga-Ge геотермометра для реконструкций условий формирования гидротермальной трубы Юбилейного медно-колчеданного месторождения (Южный Урал) // Минералы: строение, свойства, методы исследования: Материалы ХІ Всероссийской молодёжной научной конференции. - Екатеринбург: ИГГ УрО РАН, 2020. - C. 295-296

48. Бортников Н.С., Симонов В.А., Богданов Ю.А. Флюидные включения в минералах из современных сульфидных построек: физико-химические условия минералов образования и эволюция флюида // Геология рудных месторождений. 2004. - T. 46. - № 1. - С. 74-87.

49. Физико-химические параметры магматических и гидротермальных процессов на колчеданном месторождении ЯманКасы, Южный Урал / В.А. Симонов, С.В. Ковязин, Е.О. Тереня, В.В. Масленников, В.В. Зайков, С.П. Масленникова // Геология рудных месторождений. - 2006. - Т. 48. - № 5. - С. 423-438.

50. Bailly L., Orgeval J.-J., Tessalina S.G., Zaykov V.V., Maslennikov V.V. Fluid inclusion data of the Alexandrinka massive sulfide deposits, Urals // Proc. of the Fifth Biennial SGA Meeting and the Tenth Quadrennial IAGOD Symposium / Ed. by A.A. Balkema. London, United Kingdom, 22-25 August 1999. - V. 1. - P. 13-16.

51. Peter J.M., Scott S.D. Mineralogy, composition, and fluid inclusion microthermometry of seafloor hydrothermal deposits in the southern trough of Guaymas Basin, Gulf of California // Canadian Mineralogist. - 1988. - V. 26. - P. 567-587.

52. Vanko D.A., Milby B.J., Heinzquith S.W. Massive sulphides with fluid-inclusion-bearing quartz from a young seamount on the East Pacific Rise // Canadian Mineralogist. - 1991. - V. 29. - P. 453-460.

53. Active and relict sea-floor hydrothermal mineralization at the TAG hydrothermal field, Mid-Atlantic Ridge / P.A. Rona, M.D. Hannington, C.V. Raman, G. Thompson, M.K. Tivey, S.E. Humphis, C. Lalou, S. Petersen // Economic Geology. - 1993. - V. 88. P. 1989-2017.

54. Бортников Н.С., Викентьев И.В. Современное сульфидное полиметаллическое минералообразование в мировом океане // Геология рудных месторождений. - 2005. - Т. 47. - № 1. C. $16-50$.

55. Effects of fluid boiling on $\mathrm{Au}$ and volatile element enrichment in submarine arc-related hydrothermal systems / J.J. Falkenberg, M.
Keith, K.M. Haase, W. Bach, R. Klemd, H. Strauss, I.A. Yeo, K.H Rubin, B. Storch, M.O. Anderson // Geochimica et Cosmochimica Acta. - 2021. - V. 307. - P. 105-132.

56. Effects of magmatic volatile influx in mafic VMS hydrothermal systems: evidence from the Troodos ophiolite, Cyprus / A.J. Martin, M. Keith, D.B. Parvaz, I. McDonald, A.J. Boyce, K.A. McFall, G.R.T. Jenkin, H. Strauss, C.J. MacLeod // Chemical Geology. 2020. - V. 531. - P. 119-325.

57. Sudarikov S., Narkenvsky E., Petrov V. Identification of two new hydrothermal fields and sulfide deposits on the Mid-Atlantic Ridge as a result of the combined use of exploration methods: methane detection, water column chemistry, ore sample analysis, and camera surveys // Minerals. - 2021. - V. 11. - № 7. - P. 726.

58. Carbonic fluid overprints in volcanogenic massive sulfide deposits: examples from The Kelan volcano-sediventary basin, Altaides, China / J. Xu, C.J. Hart, L. Wang, H. Chu, L. Lin, X. Wei // Economic Geology. - 2011. - V. 106. - P. 145-158.

59. Бороденков А.Г., Русинов В.Л. Физико-химические условия образования карбонатов и некоторых рудных месторождений // Геохимия. - 1982. - № 9. - С. 1257-1276.

60. Грабежев А.И., Ронкин Ю.Л. Изотопы углерода, кислорода и стронция в карбонатах медно-скарновых месторождений Урала // Литосфера. - 2007. - № 4. - С. 102-114.

61. De Ronde C.E.J. Fluid chemistry and isotopic characteristics of seafloor hydrothermal systems and associated VMS deposits: potential for magmatic contributions // Magmas, fluids, and ore deposits. Mineralogical Association of Canada Short Course Series // Ed. by J.F.H. Thompson. - 1995. - V. 23. - P. 479-509.

62. Mineral-scale in the metal and sulfur isotope composition of pyrite: implications for metal and sulfur sources in mafic VMS deposits / A.J. Martin, I. McDonald, J.W. Jamieson, G.R. Jenkin, K.A. McFall, G. Piercey, C.J. MacLeod, G.D. Layne // Mineralium Deposita. - 2021. - V. 368. - P. 1-23.

63. Kampschulte A., Strauss H. The sulfur isotopic evolution of Phanerozoic seawater based on the analysis of structurally substituted sulfate in carbonates // Chemical Geology. - 2004. - V. 204. P. 255-286.

64. Trace element and sulfur isotope compositions for pyrite across the mineralization zones of a sulfide chimney from the East Pacific Rise $\left(1-2^{\circ} \mathrm{S}\right) /$ X. Meng, X. Li, F. Chu, J. Zhu, J. Lei, Z. Li, H. Wang, L. Chen, Z. Zhu // Ore Geology Reviews. - 2020. V. 116. - P. 1-15

Поступила: 03.11.2021 2.

\section{Информация об авторах}

Целуйко A.C., младший научный сотрудник Института минералогии Южно-Уральского федерального научного центра минералогии и геоэкологии УрО РАН.

Анкушева Н.Н., кандидат геолого-минералогических наук, научный сотрудник Института минералогии Южно-Уральского федерального научного центра минералогии и геоэкологии УрО РАН; доцент, ЮжноУральский государственный университет, филиал в г. Миассе.

Cadbков $\boldsymbol{C}$.A., кандидат геолого-минералогических наук, научный сотрудник Института минералогии ЮжноУральского федерального научного центра минералогии и геоэкологии УрО РАН. 
UDC 553.434: 550.42

\title{
CONDITIONS OF FORMATION AND FLUID SOURCES OF YUBILEYNOE VMS DEPOSIT (SOUTHERN URALS): FLUID INCLUSION DATA AND ISOTOPIC AND GEOCHEMICAL STUDY
}

\author{
Alexander S. Tseluyko', \\ celyukoa@rambler.ru
}

Natalia N. Ankusheva1,2, ankusheva@mail.ru

\author{
Sergey A. Sadykov ${ }^{1}$, \\ sergei_sadykov@mail.ru \\ 1 Institute of Mineralogy of South Urals Federal Research Center of Mineralogy and Geoecology UB RAS, \\ Territory of the llmeny Reserve, Miass, 456317, Russia. \\ 2 South Urals State University, branch in Miass, \\ 10, 8 lyulya street, Miass, 456304, Russia.
}

The relevance of the research is related to the problem of determining the PT ( $P$ - pressure, $T$ - temperature) and isotopic and geochemical parameters of formation of massive sulfide ore and seafloor sulfide edifices of Yubileynoe VMS deposit, including various mineral types of paleohydrothermal chimneys, sulfide diffusers and biomorfic ores, in comparison with other VMS deposits of the Southern Urals and modern ocean tubes.

The aim of the research is to determine the conditions of formation and isotopic and geochemical composition of ore-bearing fluid formed seafloor sulfide edifices from Yubileynoe VMS deposit.

The object of the research is Yubileynoe VMS deposit located in Bashkortostan Republic area in the Southern Urals.

Methods. The trace element amounts in calcite were determined using Tescan Vega 3 sbu SEM (Institute of Mineralogy SU FRC MG UB RAS, Miass). Fluid inclusions were analyzed in TMS-600 (Linkam) thermostage equipped with Olympus BX-51 microscope (SUSU, Miass). The gas phases of fluid inclusions in quartz were determined by Raman spectroscopy on a Horiba Lab Ram HR 800 spectrometer (IGM SB RAS, Novosibirsk). The isotopic compositions of carbon ( $\delta^{13} \mathrm{C} \%$ VPDB) and oxygen ( $\delta^{18} \mathrm{O} \%$ VSMOW) were carried out on a DeltaPlus Advantage mass spectrometer (Thermo Finnigan) coupled to an EA Flash 1112 elemental analyzer with a ConFlo III interface (Institute of Mineralogy SU FRC MG UB RAS, Miass).

Results. Homogenization of fluid inclusions in calcite and quartz occurred in the range between 120 and $225^{\circ} \mathrm{C}$, the salinity is $3,3-10,2$ wt. \% $\mathrm{NaCl}$ eq. A significant part of fluid inclusions $\left(T_{h}<200^{\circ} \mathrm{C}\right)$ in transparent minerals of relics of paleohydrothermal chimneys, sulfide diffusers, and calcite veinlets in collomorphic pyrite ores is probably associated with epigenetic processes of transformation of massive sulfide ores. Fluid inclusions in quartz and calcite with $T_{h}>200^{\circ} \mathrm{C}$ were probably formed during relatively low-temperature stages of primary massive sulfide formation. The isotopic composition of $\delta^{13} \mathrm{C}$ and $\delta^{18} \mathrm{O}$ of calcite, as well as the calculated values of $\delta^{18} \mathrm{O}_{22 \mathrm{O}}$ and $\delta^{13} \mathrm{C}_{\mathrm{CO} 2}$ of the oreforming fluid, indicate the mixing of seawater and magmatic fluid.

\section{Key words:}

Sulfide paleohydrothermal chimneys, fluid inclusions, $C$ and $O$ isotopes, massive sulfide deposits, Southern Urals.

The authors express thanks to the researchers of South Urals Federal Research Center of Mineralogy and Geoecology of UB RAS: Valery V. Maslennikov for assistance in preparing paper and rock material, Mikhail V. Shtenberg and Ivan A. Blinov for an alytical works, as well as to Sergey Z. Smirnov (V.S. Sobolev Institute of Geology and Mineralogy SB RAS, Novosibirsk) for the possibility to study fluid inclusions by the Raman spectroscopy method. This is the taxpayer-funded research of South Urals Federal Research Center of Mineralogy and Geoecology of UB RAS no. AAAA-A19-119061790049-3.

\section{REFERENCES}

1. Karpukhina V.S., Baranov E.N. Physical and chemical conditions of formation of the massive sulfide ore deposits of Verkhneuralsky ore area, Southern Urals. Geochemistry, 1995, no. 1, pp. 48-63. In Rus.

2. Votyakov S.L., Maslennikov V.V., Borisov D.R., Krasnobaev A.A Manganese is an indicator of carbonate mineralization formation at the zinc-copper massive sulfide deposits of the Southern Urals (Russia). Geology of ore deposits, 1996, vol. 38, no. 6, pp. 558-569. In Rus.

3. Vikentyev I.V. Usloviya formirovaniya $i$ metamorfizm kolchedannykh rud [Formation conditions and metamorphism of massive sulfide ores]. Moscow, Nauchny mir Publ., 2004. 322 p.

4. Karpukhina V.S., Naumov V.B., Vikentyev I.V. Genesis of massive sulfide deposits in the Verkhneuralsk ore district (South Ural, Russia): evidence for magmatic contribution of metals and fluids. Geology of ore deposits, 2013, vol. 55, no. 2, pp. 145-165. In Rus.
5. Soroka E.I., Pritchin M.E., Lyutoev V.P., Smoleva I.V. Physicochemical studies of carbonates from the Safyanovsky massive copper sulfide deposit (Middle Urals). Bulletin of the Perm University. Geology, 2019, vol. 18, no. 2, pp. 152-164. In Rus.

6. Amplieva E.E., Vikentyev I.V., Karpukhina V.S., Bortnikov N.S. Rol magmaticheskogo flyuida $\mathrm{v}$ formirovanii Talganskogo mednotsinkovo-kolchedannogo mestorozhdeniya, Yuzhnyy Ural [The role of magmatic fluid in the formation of the Talgan copper-zinc massive sulfide deposit, South Ural]. Doklady Earth Sciences, 2008, vol. 423, no. 4, pp. 516-519.

7. Maslennikova S.P., Maslennikov V.V. Sulfidnye truby paleozoyskikh «chernykh kurilshchikov» (na primere Urala) [Paleozoic «black smoker» sulfide chimneys]. Yekaterinburg, Miass, UB RAS Publ., 2007. 312 p.

8. Maslennikov V.V., Maslennikova S.P., Lein A.Yu. Mineralogiya $i$ geokhimiya drevnikh $i$ sovremennykh chernykh kurilshchikov [Mineralogy and geochemistry of ancient and modern black smokers]. Moscow, RAS Publ., 2019. 832 p. 
9. Tseluyko A.S., Maslennikov V.V., Maslennikova S.P., Danyushevsky L.V., Kotlyarov V.A., Blinov I.A. Mineralogocal and geochemical features of sulfide chimneys of the Yubileynoe massive sulfide deposit (South Urals). Mineralogy, 2019, no. 4 pp. 52-72. In Rus.

10. Maslennikov V.V., Maslennikova S.P., Large R.R., Danyushevsky L.V. Herrington R.J., Ayupova N.R., Zaykov V.V., Lein A.Yu., Tseluyko A.S., Melekestseva I.Yu., Tessalina S.G. Chimneys in Paleozoic massive sulfide mounds of the Urals VMS deposits: Mineral and trace element comparison with modern black, grey, white and clear smokers. Ore Geology Reviews, 2017, vol. 85, pp. 64-106.

11. Krasnov S.G., Cherkashev G.A., Ainemer A.I., Grintal E.F., Grichuk D.V., Davydov M.P., Poroshina I.M., Stepanova T.V., Sudarikov S. M., Bochek L.I., Datsenko V.A., Dubinin E.P., Elyanova E.A., Zairi N.M., Kolosov O.V., Mironov Yu.V., Popov V.E., Andreeva I.A., Vaganov P.A., German N.E., Gurevich N.I., Kreiter I.I., Maslov M.N. Gidrotermalnye sulfidnye rudy i metallonosnye osadki okeana [Hydrothermal sulfide ores and metalliferous ocean sediments]. St-Petersburg, Nedra Publ., 1992. $278 \mathrm{p}$.

12. Bogdanov Yu.A., Lisitsyn A.P., Sagalevich A.M., Gurvich E.G. Gidrotermalny rudogenez okeanskogo dna [Hydrothermal ore genesis of the ocean floor]. Moscow, Nauka Publ., 2006. 527 p.

13. Bortnikov N.S., Simonov V.A., Amplieva E.E., Stavrova O.O., Fouquet I. The physicochemical conditions of hydrothermal oreforming systems of "black smokers" associated with mantle ultrabasites in the Central Atlantic region. Geology and Geophysics, 2011, vol. 52, no. 11, p. 1790-1801. In Rus.

14. Rona P.A., Widenfalk L., Bostrom K. Serpentinized ultramafics and hydrothermal activity at the Mid-Atlantic Ridge crest near $15^{\circ} \mathrm{N}$ Journal of Geophysical Research: Solid Earth, 1987, vol. 92, Iss. B2, pp. 1417-1427.

15. Monecke T., Petersen S., Hannington M.D., Grant H., Samson I.M. The minor element endowment of modern sea-floor massive sulfides and comparison with deposits hosted in ancient volcanic successions. Economic Geology, 2016, vol. 18, no. 8, pp. 245-306.

16. Falkenberg J.J., Keith M., Haase K.M., Bach W., Klemd R. Strauss H., Yeo I.A., Rubin K.H., Storch B., Anderson M.O. Effects of fluid boiling on $\mathrm{Au}$ and volatile element enrichment in submarine arc-related hydrothermal systems. Geochimica et Cosmochimica Acta, 2021, vol. 307, pp. 105-132.

17. Tseluyko A.S., Maslennikov V.V., Ayupova N.R., Sadykov S.A Sulfur isotopic composition of sulfide from the destruction products of paleosmokers from the Yubileynoe VHMS deposit (Southern Urals). Mineralogy, 2015, no. 4, p. 103-111. In Rus.

18. Tseluyko A.S., Ankusheva N.N. Usloviya formirovaniya trub «paleokurilshchikov» Yubileynogo mednokolchedannogo mestorozhdeniya (Yuzhnyy Ural) po dannym termobarogeokhimii KR-spektroskopii [Conditions for the formation of sulfide chimneys of «paleosmokers» of the Yubileynoe massive sulfide deposit (South Urals) according to thermobarogeochemistry and Raman spectroscopy]. Metallogeniya $i$ sovremennykh okeanov-2016 [Metallogeny of ancient and modern oceans-2016]. Miass, Institute of Mineralogy, UB RAS, 2016. pp. 101-106.

19. Ankusheva N.N., Tseluyko A.S., Shtenberg M.V. Usloviya formirovaniya Yubileynogo mestorozhdeniya (Yuzhnyy Ural) po dannym termobarogeokhimii i kolebatelnoy spektroskopii [Conditions for the formation of the Yubileynoe massive sulfide deposit (South Urals) according to thermobarogeochemistry and Raman spectroscopy]. Nauka YUUrGU. Materialy 68-y nauchnoy konferentsii Sektsii estestvennykh nauk [Science of SUSU. Proceedings of the 68th scientific conference of the natural sciences section]. Chelyabinsk, SUSU Publ., 2016. pp. 239-247.

20. Kosarev A.M. O rezultatakh razrabotki modeley rudnomagmaticheskikh sistem devonskikh kolchedanonosnykh vulkanicheskikh kompleksov Magnitorskoy ostrovoduzhnoy megazony, Yuzhnyy Ural [On the results of the development of models of ore-magmatic systems of Devonian pyrite-bearing volcanic complexes of the Magnitorsk island-arc megazone, South Ural] Metallogeniya i sovremennykh okeanov-2021 [Metallogeny of ancient and modern oceans-2021]. Miass, Institute of Mineralogy UB RAS Publ., 2021. pp. 10-12.

21. Kosarev A.M., Svetov S.A., Chazhengina S.Yu., Shafigullina G.T. Boninitic variolites of the Buribay volcanic complex the Southern
Urals: mineralogy, geochemistry and formation conditions. Litosphera, 2018, vol. 18, pp. 246-279. In Rus.

22. Vorobiev V.V., Popov E.V., Saponov A.V., Antoshkin D.M., Popova L.P. Otchet o detalnoy razvedke Yubileynogo mednokolchedannogo mestorozhdeniya na Yuzhnom Urale v 1969-73 gg. [Report on detailed exploration of the Yubileynoe massive sulfide deposit in the South Urals in 1969-73]. Buribai, Perevolochansk exploration expedition, 1973. Vol. 1,351 p.

23. Georgieva M.N., Little C.T.S., Maslennikov V.V., Glover A.G., Ayupova N.R., Herrington R.J. The history of life at hydrothermal vent. Earth-Science Reviews, 2021, vol. 217, pp. 1-21.

24. Borisenko A.S. Izuchenie solevogo sostava rastvorov gazovozhidkikh vklyucheniy v mineralakh metodom kriometrii [Study of the salt composition of solutions of gas-liquid inclusions in minerals by the cryometry method]. Geology and Geophysics, 1977, no. 8 , pp. $16-28$

25. Davis D.W., Lowenstein T.K., Spenser R.J. Melting behavior of fluid inclusions in laboratory-grown halite crystals in the systems $\mathrm{NaCl}-\mathrm{H}_{2} \mathrm{O}, \mathrm{NaCl}-\mathrm{KCl}-\mathrm{H}_{2} \mathrm{O}, \mathrm{NaCl}-\mathrm{MgCl}_{2}-\mathrm{H}_{2} \mathrm{O}$ and $\mathrm{CaCl}_{2}-\mathrm{NaCl}-$ $\mathrm{H}_{2} \mathrm{O}$. Geochimica Et Cosmochimica Acta, 1990, vol. 54 (3), pp. 591-601.

26. Spenser R.J., Moller N., Weare J.N. The prediction of mineral solubilities in mineral waters: a chemical equilibrium model for the $\mathrm{Na}-\mathrm{K}-\mathrm{Ca}-\mathrm{Mg}-\mathrm{Cl}-\mathrm{SO}_{4}$ system at temperatures below $25^{\circ} \mathrm{C}$. Geochimica Et Cosmochimica Acta, 1990, vol. 54 (3), pp. 575-590.

27. Bodnar R.J., Vityk M.O. Interpretation of microthermometric data for $\mathrm{H} 2 \mathrm{O}-\mathrm{NaCl}$ fluid inclusions. Fluid inclusions in minerals: methods and applications. Pontignana-Siena, 1994, pp. 117-130.

28. Burke E.A.J. Raman microspectrometry of fluid inclusions. Lithos, 2001, vol. 55, no. 1, pp. 139-158

29. Ohmoto H., Rye R.O. Isotopes of sulfur and carbon. Geochemistry of hydrothermal ore deposits. Ed. by H.L. Barner. New York, Wiley, 1979. pp. 509-567.

30. Znamenskiy S.E., Ankusheva N.N. Bolshekaranskoe i Nikolaevskoe zolotorudnye mestorozhdeniya (Yuzhnyy Ural): flyuidnye vklyucheniya, elementy-primesi i stabilnye izotopy S, C i O v mineralakh rudnykh zhil [Bolshekaran and Nikolaevskoe gold deposits (South Urals): fluid inclusions, trace elements and stable isotopes of $\mathrm{S}, \mathrm{C}$ and $\mathrm{O}$ in minerals of ore veins]. Metallogeniya drevnikh i sovremennykh okeanov-2019 [Metallogeny of ancient and modern oceans-2019]. Miass, Institute of Mineralogy UB RAS, 2019. pp. $160-163$

31. Bowman J.R. Stable isotope systematic of skarns. Mineralized intrusion-related Skarn systems. Ed. by D.R. Lentz. Canada, Mineralogical Association of Canada Short Course Series, 1998. pp. 99-146.

32. Vikentyev I.V. Usloviya formirovaniya $i$ metamorfizm kolchedannykh rud [Formation conditions and metamorphism of massive sulfide ores]. Moscow, Nauchny mir Publ., 2004. 322 p.

33. Veizer J., Hoefs J. The nature of $\mathrm{O}^{18} / \mathrm{O}^{16}$ and $\mathrm{C}^{13} / \mathrm{C}^{12}$ secular trends in sedimentary carbonate rocks. Geochimica et Cosmochimica Acta, 1976, vol. 40, pp. 1387-1395.

34. Kerrich R. Carbon-isotope systematics of Archean Au-Ag vein deposit in the Superior Province. Canadian Journal Earth Science, 1990, vol. 27, pp. 40-56.

35. Bogdanov Yu.A., Bortnikov N.S., Vikentyev I.V., Lein A.Yu., Gurvich E.G., Sagalevich A.M., Simonov V.A., Ikorsky S.V., Stavrova O.O., Apollo V.N. Mineralogical and geochemical features of hydrothermal sulfide ores of the Rainbow field associated with serpentinites, MAR $\left(36^{\circ} 4\right.$ 'N). Geology of Ore Deposits, 2002, vol. 44, no. 6, pp. 510-542. In Rus.

36. Amplieva E.E. Geologicheskoe stroenie, mineralogogeokhimicheskie osobennosti i usloviya obrazovaniya Talganskogo kolchedannogo mestorozhdeniya, Yuzhnyy Ural. Avtoreferat Diss. Kand. nauk [Geological structure, mineralogical and geochemical features and conditions of formation of the Talgan deposit, South Urals. Cand. Diss. Abstract]. Moscow, 2008. 38 p.

37. Tornos F., Gonza'lez-Clavijo E., Spiro B. The Filo'n Norte orebody (Tharsis, Iberian Pyrite Belt): a proximal low-temperature shale-hosted massive sulphide in a thin-skinned tectonic belt. Mineralium Deposita, 1998, vol. 33, pp. 150-169.

38. Relvas J.M.R.S. Geology and metallogenesis at the Neves Corvo deposit, Portugal. PhD Thesis. Portugal, University of Lisbon, 2000. 319 p.

39. Sanchez-Espana J., Velasco F., Boyce A.J., Fallick A.E. Source and evolution of ore-forming hydrothermal fluids in the northern 
Iberian Pyrite Belt massive sulphide deposits (SW Spain): evidence from fluid inclusions and stable isotopes. Mineralium. Deposita, 2003, vol. 38, pp. 519-537.

40. McCuaig T.C., Kerrich R. P-T-t-deformation-fluid characteristics of lode gold deposits: evidence from alteration systematics. Ore Geology Reviews, 1998, vol. 12, pp. 381-453.

41. Sheppard S.M.H. Characterization and isotopic variations in natural waters. Stable isotopes in high temperature geological processes. Eds. J.W. Valley, H.P. Taylor, J.R. O’Neil. Berlin, De Gruyter, 1986. Vol. 16, pp. 165-183

42. Valley J.W. Stable isotope geochemistry of metamorphic rocks. Stable isotopes in high temperature geological processes. Review Mineral. Eds. J.W. Valley, H.P. Taylor, J.R. O’Neil (Ed.). Berlin, De Gruyter, 1986. Vol. 16, pp. 445-489.

43. Rollinson H.R. Using geochemical data: evaluation, presentation interpretation. London, Longman Scientific and Technical, 1993. $352 \mathrm{p}$.

44. Znamensky S.E., Ankusheva N.N., Znamenskaya N.M. Termobarogeokhimicheskie parametry i izotopny sostav rud zolotoporfirovogo mestorozhdeniya Bolshoy Karan (Yuzhnyy Ural) [Thermobarogeochemical parameters and isotopic composition of ores of the Bolshoi Karan gold-porphyry deposit (South Urals)] Geologiya, poleznye iskopayemye i problemy geoekologii Bashkortostana, Urala $i$ sopredelnykh territoriy [Geology, minerals and problems of geoecology of Bashkortostan, the Urals and adjacent territories]. Ufa, IG UC RAS Publ., 2018. pp. 245-248.

45. Omoto H., Goldhaber M.B. Sulfur and carbon isotopes. Geochemistry of hydrothermal ore deposits. N.Y., John Wiley and Sons, 1997. pp. 517-611.

46. Hoefs J. Stable isotope geochemistry. $6^{\text {th }}$ ed. Berlin, Heidelberg, Springer-Verlag, 2009. $285 \mathrm{p}$.

47. Tseluyko A.S., Artemyev D.A. Primenenie Ga-Ge geotermometra dlya rekonstruktsiy usloviy formirovaniya gidrotermalnoy truby Yubileynogo medno-kolchedannogo mestorozhdeniya (Yuzhnyy Ural) [Application of Ga-Ge geothermometer for reconstructions of the conditions of formation of the hydrothermal chimney of the Yubileynoe copper massive sulfide deposit (South Urals)]. Materialy XI Vserossiyskoy molodozhnoy nauchnoy konferentsii. Mineraly: stroyenie, svoystva, metody issledovaniya [Materials of the XI All-Russian Youth Scientific Conference. Minerals: structure, properties, research methods]. Yekaterinburg, IGG UB RAS Publ., 2020. pp. 295-296.

48. Bortnikov N.S., Simonov V.A., Bogdanov Yu.A. Fluid inclusions in minerals from seafloor massive sulfide: physico-chemical conditions of mineral formation and fluid evolution. Geology of Ore Deposits, 2004, vol. 46, no. 1, pp. 74-87. In Rus.

49. Simonov V.A., Kovyazin S.V., Terenya E.O., Maslennikov V.V. Zaykov V.V., Maslennikova S.P. Physico-chemical parameters of magmatic and hydrothermal processes at the Yaman-Kasy massive sulfide deposit, South Urals. Geology of Ore Deposits, 2006, vol. 48, no. 5, pp. 423-438. In Rus.

50. Bailly L., Orgeval J.-J, Tessalina S.G., Zaykov V.V., Maslennikov V.V. Fluid inclusion data of the Alexandrinka massive sulfide deposits, Urals. Proc. of the Fifth Biennial SGA Meeting and the Tenth Quadrennial IAGOD Symposium. Ed. by A.A. Balkema. London, United Kingdom, 22-25 August 1999. Vol. 1, pp. 13-16.

51. Peter J.M., Scott S.D. Mineralogy, composition, and fluid inclusion microthermometry of seafloor hydrothermal deposits in the southern trough of Guaymas Basin, Gulf of California. Canadian Mineralogist, 1988, vol. 26, pp. 567-587.

52. Vanko D.A., Milby B.J., Heinzquith S.W. Massive sulphides with fluid-inclusion-bearing quartz from a young seamount on the East Pacific Rise. Canadian Mineralogist, 1991, vol. 29, pp. 453-460.

53. Rona P.A., Hannington M.D., Raman C.V., Thompson G., Tivey M.K., Humphis S.E., Lalou C., Petersen S. Active and relict sea-floor hydrothermal mineralization at the TAG hydrothermal field, MidAtlantic Ridge. Economic Geology, 1993, vol. 88, pp. 1989-2017.

54. Bortnikov N.S., Vikentyev I.V. Modern sulfide polymetallic mineral formation in the world ocean. Geology of Ore Deposits, 2005, vol. 47, no. 1, pp. 16-50. In Rus.

55. Falkenberg J.J., Keith M., Haase K.M., Bach W., Klemd R., Strauss H., Yeo I.A., Rubin K.H., Storch B., Anderson M.O. Effects of fluid boiling on $\mathrm{Au}$ and volatile element enrichment in submarine arc-related hydrothermal systems. Geochimica et Cosmochimica Acta, 2021, vol. 307, pp. 105-132.

56. Martin A.J., Keith M., Parvaz D.B., McDonald I., Boyce A. J., McFall K.A., Jenkin G.R.T., Strauss H., MacLeod C.J. Effects of magmatic volatile influx in mafic VMS hydrothermal systems: evidence from the Troodos ophiolite, Cyprus. Chemical Geology, 2020, vol. 531, pp. 119-325.

57. Sudarikov S., Narkenvsky E., Petrov V. Identification of two new hydrothermal fields and sulfide deposits on the Mid-Atlantic Ridge as a result of the combined use of exploration methods: methane detection, water column chemistry, ore sample analysis, and camera surveys. Minerals, 2021, vol. 11, no. 7, pp. 726.

58. Xu. J., Hart C.J., Wang L., Chu H., Lin L., Wei X. Carbonic fluid overprints in volcanogenic massive sulfide deposits: examples from The Kelan volcano-sediventary basin, Altaides, China. Economic Geology, 2011, vol. 106, pp. 145-158.

59. Borodenkov A.G., Rusinov V.L. Fiziko-khimicheskie usloviya obrazovaniya karbonatov i nekotorykh rudnykh mestorozhdeniy [Physicochemical conditions for the formation of carbonates and some ore deposits]. Geokhimiya, 1982, no. 9, pp. 1257-1276.

60. Grabezhev A.I., Ronkin Yu.L. Isotopes of carbon, oxygen and strontium in carbonates of copper-skarn deposits of the Urals. Lithosphere, 2007, no. 4, pp. 102-114. In Rus.

61. De Ronde C.E.J. Fluid chemistry and isotopic characteristics of seafloor hydrothermal systems and associated VMS deposits: potential for magmatic contributions. Magmas, fluids, and ore deposits. Ed. by J.F.H. Thompson. Canada, Quebec, Mineralogical Association of Canada Short Course Series, 1995. Vol. 23, pp. 479-509.

62. Martin A.J., McDonald I., Jamieson J.W., Jenkin G.R., McFall K.A., Piercey G., MacLeod C.J., Layne G.D. Mineral-scale in the metal and sulfur isotope composition of pyrite: implications for metal and sulfur sources in mafic VMS deposits. Mineralium Deposita, 2021, vol. 368, pp. 1-23.

63. Kampschulte A., Strauss H. The sulfur isotopic evolution of Phanerozoic seawater based on the analysis of structurally substituted sulfate in carbonates. Chemical Geology, 2004, vol. 204, pp. 255-286.

64. Meng X., Li X., Chu F., Zhu J., Lei J., Li Z., Wang H., Chen L., Zhu $Z$ Trace element and sulfur isotope compositions for pyrite across the mineralization zones of a sulfide chimney from the East Pacific Rise (1-2 ${ }^{\circ}$ S). Ore Geology Reviews, 2020, vol. 116, pp. $1-15$.

Receieved: 3 November 2021.

\section{Information about the authors}

Alexander S. Tseluyko, junior researcher, Institute of Mineralogy of South Urals Federal Research Center of Mineralogy and Geoecology UB RAS.

Natalia N. Ankusheva, Cand. Sc., researcher, Institute of Mineralogy of South Urals Federal Research Center of Mineralogy and Geoecology UB RAS; assotiate professor, South Urals State University, branch in Miass.

Sergey A. Sadykov, Cand. Sc., researcher, Institute of Mineralogy of South Urals Federal Research Center of Mineralogy and Geoecology UB RAS. 